\title{
A Review of Manganese(III) (Oxyhydr)Oxides Use in Advanced Oxidation Processes
}

\author{
Daqing Jia ${ }^{1}$, Khalil Hanna ${ }^{2,3}$, Gilles Mailhot ${ }^{1}(\mathbb{0})$ and Marcello Brigante ${ }^{1, *}(\mathbb{0})$ \\ 1 Institut de Chimie de Clermont-Ferrand, Université Clermont Auvergne, CNRS, Clermont Auvergne INP \\ SIGMA Clermont, F-63000 Clermont-Ferrand, France; daqing.jia@etu.uca.fr (D.J.); \\ gilles.mailhot@uca.fr (G.M.) \\ 2 École Nationale Supérieure de Chimie de Rennes, Université Rennes, CNRS, ISCR-UMR6226, F-35000 \\ Rennes, France; khalil.hanna@ensc-rennes.fr \\ 3 Institut Universitaire de France (IUF), MESRI, 1 rue Descartes, 75231 Paris, France \\ * Correspondence: marcello.brigante@uca.fr; Tel.: +33-047-340-5514
}

Citation: Jia, D.; Hanna, K.; Mailhot, G.; Brigante, M. A Review of Manganese(III) (Oxyhydr)Oxides Use in Advanced Oxidation Processes. Molecules 2021, 26, 5748. https:// doi.org/10.3390/molecules26195748

Academic Editor: Alireza Khataee

Received: 3 September 2021

Accepted: 21 September 2021

Published: 22 September 2021

Publisher's Note: MDPI stays neutral with regard to jurisdictional claims in published maps and institutional affiliations.

Copyright: (c) 2021 by the authors. Licensee MDPI, Basel, Switzerland. This article is an open access article distributed under the terms and conditions of the Creative Commons Attribution (CC BY) license (https:// creativecommons.org/licenses/by/ $4.0 /)$.

\begin{abstract}
The key role of trivalent manganese (Mn(III)) species in promoting sulfate radical-based advanced oxidation processes (SR-AOPs) has recently attracted increasing attention. This review provides a comprehensive summary of $\mathrm{Mn}$ (III) (oxyhydr)oxide-based catalysts used to activate peroxymonosulfate (PMS) and peroxydisulfate (PDS) in water. The crystal structures of different $\mathrm{Mn}\left(\mathrm{III}\right.$ ) (oxyhydr)oxides (such as $\alpha-\mathrm{Mn}_{2} \mathrm{O}_{3}, \gamma-\mathrm{MnOOH}$, and $\mathrm{Mn}_{3} \mathrm{O}_{4}$ ) are first introduced. Then the impact of the catalyst structure and composition on the activation mechanisms are discussed, as well as the effects of solution $\mathrm{pH}$ and inorganic ions. In the Mn(III) (oxyhydr)oxide activated SRAOPs systems, the activation mechanisms of PMS and PDS are different. For example, both radical (such as sulfate and hydroxyl radical) and non-radical (singlet oxygen) were generated by $\mathrm{Mn}(\mathrm{III})$ (oxyhydr)oxide activated PMS. In comparison, the activation of PDS by $\alpha-\mathrm{Mn}_{2} \mathrm{O}_{3}$ and $\gamma-\mathrm{MnOOH}$ preferred to form the singlet oxygen and catalyst surface activated complex to remove the organic pollutants. Finally, research gaps are discussed to suggest future directions in context of applying radical-based advanced oxidation in wastewater treatment processes.
\end{abstract}

Keywords: Mn(III) (oxyhydr)oxides; water treatment; radicals; AOPs

\section{Introduction}

Over the past few decades, with the rapid development of industrialization and the increase of anthropogenic activities, huge amounts of organic and inorganic contaminants were discharged into the surface and ground waters, causing water pollution problems and threatening human health [1-3]. However, conventional water treatment technologies, such as filtration [4,5], precipitation [6,7], coagulation-flocculation [8-10], and biological treatment $[11,12]$ exhibited a minimal effect on the removal of recalcitrant pollutants. Therefore, there is an increasing demand for efficient, economical, and environmental-friendly water treatment technologies. Advanced oxidation processes (AOPs) have attracted particular attention due to their high efficiency for removal of recalcitrant contaminant. AOPs are able to remove and mineralize most unbiodegradable pollutants into harmless compounds, such as $\mathrm{CO}_{2}, \mathrm{H}_{2} \mathrm{O}$, and inorganic ions [13]. Based on various reaction conditions, AOPs can be classified into different categories, including Fenton reaction [14], Fenton-like reaction $[15,16]$, photochemical oxidation $[17,18]$, ultrasonic oxidation $[19,20]$, electrochemical oxidation [21,22], ozone oxidation [23,24], and sulfate radical-based AOPs (SR-AOPs) [25-27]. Among them, the application of SR-AOPs for the removal of stubborn pollutants has received increasing attention due to their advantages. For instance, sulfate radical $\left(\mathrm{SO}_{4}^{--}\right)$has a longer lifetime compared with the hydroxyl radical $\left(\mathrm{HO}^{\bullet}\right)$, a wide range of $\mathrm{pH}$ adaptation, and a high reduction potential (2.5-3.1 $\mathrm{V}$ vs. NHE) [28].

Generally, the peroxydisulfate (PDS, $\mathrm{S}_{2} \mathrm{O}_{8}^{2-}$ ) and peroxymonosulfate anions (PMS, $\mathrm{HSO}_{5}^{-}$) are employed as the radical precursors for producing sulfate radicals through 
breaking the O-O bonds of precursors. In comparison with PMS, PDS has a longer O-O bonds distance (1.497 vs. $1.460 \AA$ ) and lower bond energy (140 vs. $140-213.3 \mathrm{~kJ} / \mathrm{mol})[29,30]$. Therefore, PDS is theoretically easier than PMS to be cleaved to generate $\mathrm{SO}_{4}^{\bullet-}$. However, considering the unsymmetrical structure of PMS, it was reported that PMS activation was convenient for the removal of organic pollutants [31,32]. There are various ways to activate PMS and PDS to produce $\mathrm{SO}_{4}^{\cdot-}$, for example, heat, $\mathrm{UV}$, alkaline solution, metal ions, and minerals [33-37].

The activation of PMS/PDS by different transition metal ions (i.e., Co(II), $\mathrm{Ru}(\mathrm{III})$, $\mathrm{Fe}(\mathrm{II}), \mathrm{Fe}(\mathrm{III}), \mathrm{Ag}(\mathrm{I}), \mathrm{Mn}(\mathrm{II}), \mathrm{Ni}(\mathrm{I})$, and V(III)) for organic pollutant degradation has been reported [32]. The results showed that PMS can be efficiently activated by $\mathrm{Co}(\mathrm{II})$ and $\mathrm{Ru}(\mathrm{III})$, while $\mathrm{Ag}(\mathrm{I})$ was identified as the best catalyst for PDS activation. However, the high price of $\mathrm{Ag}(\mathrm{I}), \mathrm{Ru}(\mathrm{III})$, and $\mathrm{Co}(\mathrm{II})$ restricts their application in practical water treatment. In comparison, the activation of PMS/PDS by the transition metal-based minerals (such as magnetite, birnessite, and manganite) has attracted much attention due to their various advantages, such as wide resources, easy recycling, and low energy requirement [38,39]. Among the transition metal oxides, the manganese oxides have been widely developed in PMS/PDS activation for recalcitrant pollutant degradation due to their excellent properties, such as various Mn valences, ubiquitous existence, cost-efficiency, and low toxicity [40]. For instance, $\mathrm{Zhu}$ et al. employed the $\beta-\mathrm{MnO}_{2}$ nanorods to activate PDS for the removal of phenol. Efficient degradation of phenol was achieved in $\beta-\mathrm{MnO}_{2} / \mathrm{PDS}$ system through the generation of singlet oxygen $\left({ }^{1} \mathrm{O}_{2}\right)$ [41]. Zhou et al. indicated the higher catalytic property of $\alpha-\mathrm{MnO}_{2}$ than $\delta-\mathrm{MnO}_{2}$ in PMS activation for 4-nitrophenol degradation because $\alpha-\mathrm{MnO}_{2}$ owns more active sites, larger Brunauer-Emmett-Teller (BET) area, faster electron transfer rate, and better adsorption performance [42]. Furthermore, the activation of $\mathrm{PMS}$ by $\mathrm{MnO}_{2}$ with different crystal phases (i.e., $\alpha-, \beta-, \gamma-$, and $\delta-\mathrm{MnO}_{2}$ ) was reported by Huang et al. [43]. The results demonstrated the important role of crystalline structure and $\mathrm{Mn}$ (III) content on the catalytic reactivity of $\mathrm{MnO}_{2}$. Saputra et al. investigated the effect of Mn oxidation states (such as $\mathrm{MnO}, \mathrm{Mn}_{2} \mathrm{O}_{3}, \mathrm{Mn}_{3} \mathrm{O}_{4}$, and $\mathrm{MnO}_{2}$ ) on the activation of PMS for phenol degradation. The results showed that $\mathrm{Mn}_{2} \mathrm{O}_{3}$ has the highest ability on PMS activation among these four manganese oxides [44]. Therefore, the structure of manganese oxides and the content of $\mathrm{Mn}$ (III) on the surface of manganese oxides play a critical role in the oxidative and catalytic reactivity of manganese oxides. The performance of $\mathrm{MnO}_{2}$ on PDS/PMS activation was well summarized in previous reviews [45-47]. However, no attempt has been made to provide a comprehensive review on Mn(III) (oxyhydr)oxides activated PMS/PDS for recalcitrant pollutants removal.

In light of the above information, this review aims to provide a comprehensive summary of reported $\mathrm{Mn}(\mathrm{III})$-based catalysts in activating PMS/PDS. The structures of commonly used $\mathrm{Mn}$ (III) (oxyhydr)oxides $\left(\alpha-\mathrm{Mn}_{2} \mathrm{O}_{3}, \mathrm{Mn}_{3} \mathrm{O}_{4}\right.$, and $\left.\gamma-\mathrm{MnOOH}\right)$ are first presented, then the effect of structure on the reactivity of Mn(III) (oxyhydr)oxides are discussed. Moreover, the radical and non-radical mechanisms of PMS/PDS activation by a single or combined $\mathrm{Mn}$ (III) species are summarized and the influence factors affecting the reactivity of $\mathrm{Mn}$ (III) (oxyhydr)oxides are introduced.

We are convinced that this review article will be of significant interest for researchers working on chemical oxidation for water decontamination processes. Finally, we also highlight how the literature lacks information and data that are crucial prior to high-scale applications.

\section{Effect of Structure on the Reactivity of Mn(III) (Oxyhydr)Oxides}

The oxidative and catalytic performance of manganese oxides can be affected by various structural factors including crystal phases, morphologies, crystal facets, and structural dimensionalities [48]. For instance, Huang et al. reported that $\delta-\mathrm{MnO}_{2}$ showed higher oxidative activity than $\alpha-, \beta-, \gamma-, \lambda-\mathrm{MnO}_{2}$ on bisphenol A oxidation due to the occurrence of more accessible active sites in layered $\delta-\mathrm{MnO}_{2}$ than other tunnel structured $\mathrm{MnO}_{2}$ [49]. 
The authors also demonstrated the effects of structured $\mathrm{MnO}_{2}$ on peroxymonosulfate (PMS) activation, and the low reactivity of $\delta-\mathrm{MnO}_{2}$ was attributed to its less crystallinity [43].

Crystalline manganese oxides are generally built on the same basic unit $\left[\mathrm{MnO}_{6}\right]$ octahedral with the edges or corners sharing [41]. The commonly reported $\mathrm{Mn}$ (III) (oxyhydr)oxides include manganese(III) oxide $\left(\alpha-\mathrm{Mn}_{2} \mathrm{O}_{3}\right)$, groutite $(\alpha-\mathrm{MnOOH})$, feitknechtite $(\beta-\mathrm{MnOOH})$, manganite $(\gamma-\mathrm{MnOOH})$, and hausmannite $\left(\mathrm{Mn}_{3} \mathrm{O}_{4}\right)$. The structures covered in the name of $\mathrm{Mn}$ (III) (oxyhydr)oxides are summarized in Table 1. Among them, $\alpha-\mathrm{Mn}_{2} \mathrm{O}_{3}, \gamma-\mathrm{MnOOH}$, and $\mathrm{Mn}_{3} \mathrm{O}_{4}$ have attracted increasing attention from the scientific community because of their promising technological applications, such as in catalysis, water treatment, and ion exchange. The crystalline structure of $\alpha-\mathrm{Mn}_{2} \mathrm{O}_{3}$ was recognized as the body-centered cubic bixbyite phase, as shown in Figure 1a. $\gamma-\mathrm{MnOOH}$ possesses a typical $(1 \times 1)$ tunnel structure constructed by $\left[\mathrm{MnO}_{6}\right]$ octahedral sharing the corners (Figure $1 \mathrm{~b}$ ). The structure of $\gamma-\mathrm{MnOOH}$ is analogous to that of pyrolusite, except that one-half of the oxygen atoms are replaced by hydroxyl anions compared with pyrolusite. For the crystalline $\mathrm{Mn}_{3} \mathrm{O}_{4}$, it exhibits a normal spinel structure with the formula $\mathrm{Mn}^{2+}\left(\mathrm{Mn}^{3+}\right)_{2} \mathrm{O}_{4}$ where the $\mathrm{Mn}^{2+}$ and $\mathrm{Mn}^{3+}$ ions occupy the tetrahedral and octahedral sites, respectively (Figure 1c).

Table 1. The structures of common Mn(III) (oxyhydr)oxides [50,51].

\begin{tabular}{cccc}
\hline Mineral Name & Chemical Formula & Mn Valence & Crystal Structure \\
\hline Mn(III) oxide & $\alpha-\mathrm{Mn}_{2} \mathrm{O}_{3}$ & III & Bixbyite \\
Groutite & $\alpha-\mathrm{MnOOH}$ & III & Tunnel \\
Feitknechtite & $\beta-\mathrm{MnOOH}$ & III & Layer \\
Manganite & $\gamma-\mathrm{MnOOH}_{3}$ & III & Tunnel \\
Hausmannite & $\mathrm{Mn}_{3} \mathrm{O}_{4}$ & II $/ \mathrm{III}$ & Spinel \\
\hline
\end{tabular}

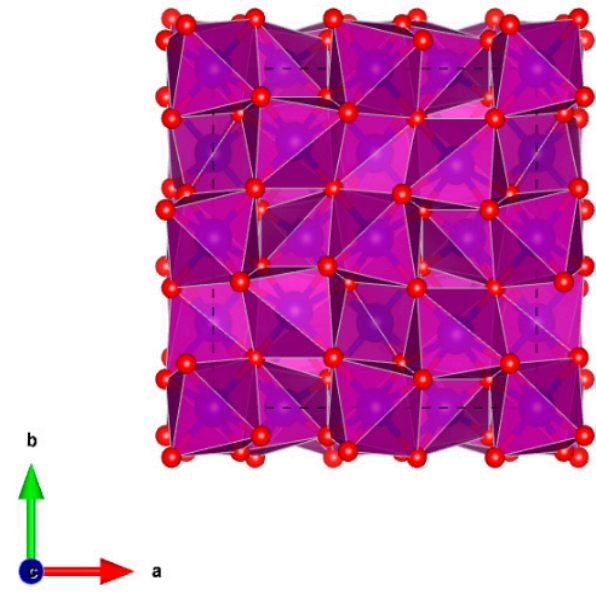

(a)
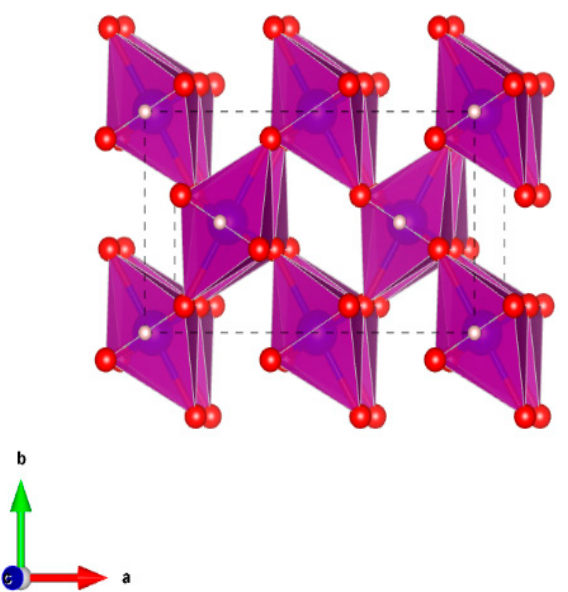

Figure 1. Cont.

(b) 


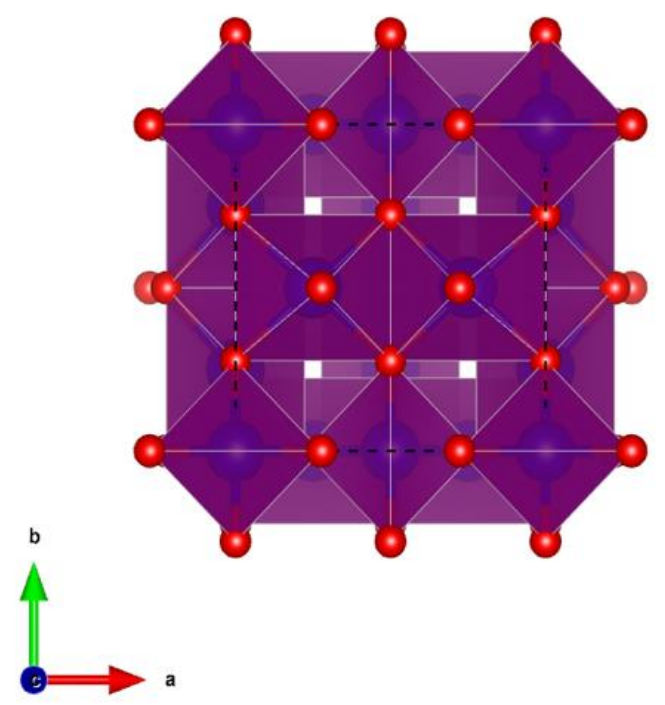

(c)

Figure 1. Structural representations of $\alpha-\mathrm{Mn}_{2} \mathrm{O}_{3}(\mathbf{a}), \gamma-\mathrm{MnOOH}(\mathbf{b})$, and (c) $\mathrm{Mn}_{3} \mathrm{O}_{4}$. The red, blue, and white balls represent oxygen, manganese, and hydrogen atoms, respectively. The black dashed lines represent the single unit cell. The crystalline parameters of $\mathrm{Mn}(\mathrm{III})$ (oxyhydr)oxides were taken from the crystallography open database (COD), and the COD ID of $\alpha-\mathrm{Mn}_{2} \mathrm{O}_{3}, \gamma-\mathrm{MnOOH}$, and $\mathrm{Mn}_{3} \mathrm{O}_{4}$ are 2105791, 1011012, and 1514121, separately [52-54].

The influence of structures in the reactivity of common $\mathrm{Mn}$ (III) (oxyhydr)oxides is summarized in Table 2. For instance, Saputra et al. investigated the effect of morphology on the oxidation of phenol by $\mathrm{Mn}_{2} \mathrm{O}_{3}$ activated PMS. The results showed that cubic $-\mathrm{Mn}_{2} \mathrm{O}_{3}$ has the highest reactivity on PMS activation in comparison with octahedral- and truncated octahedral- $\mathrm{Mn}_{2} \mathrm{O}_{3}$, and it was due to the high surface area and distinct surface atoms arrangement of cubic- $\mathrm{Mn}_{2} \mathrm{O}_{3}$ [55]. Similarly, Cheng et al. successfully prepared three $\alpha-\mathrm{Mn}_{2} \mathrm{O}_{3}$ in cubic-, truncated octahedral-, and octahedral-structure, and investigated the effect of crystal facets on the combustion of soot [56]. The results show that the soot combustion efficiency followed the order of $\alpha-\mathrm{Mn}_{2} \mathrm{O}_{3}$-cubic $>\alpha-\mathrm{Mn}_{2} \mathrm{O}_{3}$-truncated octahedral $>\alpha-\mathrm{Mn}_{2} \mathrm{O}_{3}$-octahedral. The enhanced reactivity of $\alpha-\mathrm{Mn}_{2} \mathrm{O}_{3}$-cubic was explained by the fact that the exposed (001) surface facets of $\alpha-\mathrm{Mn}_{2} \mathrm{O}_{3}$-cubic have higher amounts of lowcoordinated surface oxygen sites, which are capable of facilitating the oxygen activation and improving the surface redox properties.

In addition to $\alpha-\mathrm{Mn}_{2} \mathrm{O}_{3}$, it was also reported that the oxidative and catalytic performances of $\mathrm{Mn}_{3} \mathrm{O}_{4}$ and $\gamma-\mathrm{MnOOH}$ were affected by their structures. For example, Ji et al. reported that the hexagonal nanoplate $\mathrm{Mn}_{3} \mathrm{O}_{4}$ exhibited superior catalytic performance on diesel soot combustion compared to the octahedral and nanoparticle $\mathrm{Mn}_{3} \mathrm{O}_{4}$, and the finding was explained by the improved amount of surface $\mathrm{Mn}^{4+}$ species and surface reactive oxygen species due to the increased fraction of exposed (112) facets in hexagonal nanoplate $\mathrm{Mn}_{3} \mathrm{O}_{4}$ [57]. The effect of morphology was also discovered by Liu et al., which demonstrated that the nanoflake $\mathrm{Mn}_{3} \mathrm{O}_{4}$ (exposure of (001) facet) has the highest oxygen reduction reactivity in comparison to nanoparticle $\mathrm{Mn}_{3} \mathrm{O}_{4}$ and nanorod $\mathrm{Mn}_{3} \mathrm{O}_{4}$ (exposure of (101) facet) [58]. In addition, He et al. investigated the activation of PMS by $\gamma-\mathrm{MnOOH}$ with different shapes, and the results showed that the catalytic activity of $\gamma-\mathrm{MnOOH}$ followed the order of nanowires $>$ multi-branches $>$ nanorods [59]. Different physicochemical parameters, such as specific surface area, Lewis sites, zeta-potential, and redox potential were measured to study the reason for the different catalytic performances of $\gamma$-MnOOH with distinct morphologies. It was found that the charge density on the surface played a crucial role in the interfacial reactivity between PMS and $\gamma$-MnOOH. In summary, the reactivity of $\mathrm{Mn}(\mathrm{III})$ (oxyhydr)oxides on radical precursor activation and pollutant 
oxidation can be deeply affected by their structures. The desirable morphologies and facets (such as cubic structure with (001) facet exposure) can apparently improve the reactivity of Mn(III) (oxyhydr)oxides.

Table 2. The effect of structures on the reactivity of $\mathrm{Mn}$ (III) (oxyhydr)oxides.

\begin{tabular}{|c|c|c|c|c|c|}
\hline Catalysts & Structure & Initial Conditions & Reactivity & Mechanism & Ref. $^{1}$ \\
\hline$\alpha-\mathrm{Mn}_{2} \mathrm{O}_{3}$ & $\begin{array}{l}\text { Cubic; } \\
\text { octahedral; } \\
\text { truncated } \\
\text { octahedral }\end{array}$ & $\begin{array}{c}{[\text { Catalyst }]=0.4 \mathrm{~g} / \mathrm{L}} \\
{[\text { PMS }]=2 \mathrm{~g} / \mathrm{L}} \\
{[\text { Phenol }]=25 \mathrm{ppm}}\end{array}$ & $\begin{array}{l}100 \% \text { of phenol removal by } \\
\text { cubic- } \mathrm{Mn}_{2} \mathrm{O}_{3} \text { in } 60 \mathrm{~min}\end{array}$ & $\begin{array}{l}\text { High surface area and } \\
\text { surface atoms } \\
\text { arrangement of } \\
\text { cubic- } \mathrm{Mn}_{2} \mathrm{O}_{3}\end{array}$ & [55] \\
\hline$\alpha-\mathrm{Mn}_{2} \mathrm{O}_{3}$ & $\begin{array}{l}\text { Cubic; } \\
\text { octahedral; } \\
\text { truncated } \\
\text { octahedral }\end{array}$ & $\begin{array}{l}{[\text { Catalyst }]=4 \mathrm{~g} / \mathrm{L}} \\
{[\text { Glycerol }]=20 \mathrm{~g} / \mathrm{L}}\end{array}$ & $\begin{array}{c}\text { High catalytic activity }(0.87 \\
\left.\text { mmol } /\left(\mathrm{h} \mathrm{m}^{2}\right)\right) \text { and high } \\
\text { selectivity for glycerol }(52.6 \%) \\
\text { was achieved by } \\
\alpha-\mathrm{Mn}_{2} \mathrm{O}_{3} \text {-truncated octahedral }\end{array}$ & $\begin{array}{l}\text { Co-exposed (001) and } \\
(111) \text { facets of } \\
\alpha-\mathrm{Mn}_{2} \mathrm{O}_{3} \text {-truncated } \\
\text { octahedral }\end{array}$ & {$[60]$} \\
\hline$\alpha-\mathrm{Mn}_{2} \mathrm{O}_{3}$ & $\begin{array}{l}\text { Octahedral; } \\
\text { truncated } \\
\text { octahedral }\end{array}$ & $\begin{array}{c}180 \text { mg of catalysts; } \\
500 \text { ppm of } \mathrm{NO}^{\prime} \\
500 \text { ppm of } \mathrm{NH}_{3} ; \\
5 \% \text { v/v of } \mathrm{O}_{2} ; \\
\mathrm{N}_{2} \text { as balance gas; } \\
36,000 \mathrm{~h}^{-1} \text { of GSHV; }\end{array}$ & $\begin{array}{c}\text { High } \mathrm{NO} \text { turnover frequency } \\
\left((3.6 \pm 0.1) \times 10^{-3} \mathrm{~s}^{-1}\right) \text { was } \\
\text { achieved by } \\
\alpha-\mathrm{Mn}_{2} \mathrm{O}_{3} \text {-truncated octahedral } \\
\text { at } 513 \mathrm{~K}\end{array}$ & $\begin{array}{c}\text { The exposure of a small } \\
\text { fraction of }(001) \text { facets in } \\
\alpha-\mathrm{Mn}_{2} \mathrm{O}_{3} \text {-truncated } \\
\text { octahedral }\end{array}$ & {$[61]$} \\
\hline$\alpha-\mathrm{Mn}_{2} \mathrm{O}_{3}$ & $\begin{array}{l}\text { Cubic; } \\
\text { octahedral; } \\
\text { truncated } \\
\text { octahedral }\end{array}$ & $\begin{array}{l}100 \mathrm{mg} \text { of catalysts; } \\
10 \mathrm{mg} \text { of soot; } \\
5 \% \text { v/v of } \mathrm{O}_{2} ; \\
0.25 \% \text { v/v of } \mathrm{NO} ; \\
\mathrm{N}_{2} \text { as balance gas; } \\
9990 \mathrm{~h}^{-1} \text { of GSHV; }\end{array}$ & $\begin{array}{l}96.3,89.7 \text {, and } 85.2 \% \text { of soot } \\
\text { combustion efficiencies were } \\
\text { observed with the catalysis of } \\
\alpha-\mathrm{Mn}_{2} \mathrm{O}_{3} \text {-cubic, -truncated } \\
\text { octahedral, -octahedral }\end{array}$ & $\begin{array}{l}\text { The exposed (001) facet } \\
\text { of cubic } \mathrm{Mn}_{2} \mathrm{O}_{3}\end{array}$ & [56] \\
\hline$\stackrel{\gamma^{-}}{\mathrm{MnOOH}}$ & $\begin{array}{l}\text { Nanowires; } \\
\text { multi-branches; } \\
\text { nanorods }\end{array}$ & $\begin{array}{c}{[\text { Catalyst }]=0.3 \mathrm{~g} / \mathrm{L} ;} \\
{[\mathrm{PMS}]=12 \mathrm{mM} ;} \\
{[2,4-\mathrm{DCP}]^{2}=100 \mathrm{mg} / \mathrm{L} ;} \\
\mathrm{pH}=7\end{array}$ & $\begin{array}{l}98 \%, 88 \% \text {, and } 55 \% \text { removal of } \\
2,4-\mathrm{DCP} \text { was achieved in } \\
\gamma \text {-MnOOH nanowires, } \\
\text { multi-branches, and nanorods } \\
\text { activated PMS systems, } \\
\text { separately }\end{array}$ & $\begin{array}{c}\text { Higher zeta-potential } \\
\text { value of nanowires } \\
\gamma-\mathrm{MnOOH}\end{array}$ & [59] \\
\hline $\mathrm{Mn}_{3} \mathrm{O}_{4}$ & $\begin{array}{c}\text { Nano-cubic; } \\
\text { nano-plate; } \\
\text { nano-octahedral }\end{array}$ & $\begin{array}{c}{[\text { Catalyst }]=0.2 \mathrm{~g} / \mathrm{L} ;} \\
{[\mathrm{PMS}]=0.65 \mathrm{mM}} \\
{[\mathrm{CIP}]^{3}=10 \mathrm{mg} / \mathrm{L}} \\
\mathrm{pH}=7.7\end{array}$ & $\begin{array}{c}100 \% \text { CIP removal in } 80 \text { min by } \\
\mathrm{Mn}_{3} \mathrm{O}_{4} \text { nano-octahedral }\end{array}$ & $\begin{array}{l}\text { Lager surface } \mathrm{Mn}(\mathrm{IV}) \\
\text { contents of } \mathrm{Mn}_{3} \mathrm{O}_{4} \\
\text { nano-octahedral }\end{array}$ & {$[62]$} \\
\hline
\end{tabular}

${ }^{1}$ Ref.: Reference; ${ }^{2}$ 2,4-DCP: 2,4-dichlorophenol; ${ }^{3}$ CIP: ciprofloxacin.

\section{Mechanisms of PMS/PDS Activation by Mn(III) (Oxyhydr)Oxides}

\subsection{Activation of PMS by Mn(III) (Oxyhydr)Oxides}

The Mn(III) (oxyhydr)oxides/PMS system has been applied for the removal of a number of contaminants, such as phenol, bisphenol A, 2,4-dichlorophenol, ciprofloxacin, and organic dyes [62-67]. Different studies involving PMS activation by Mn(III) (oxyhydr)oxides are gathered in Table 3. According to the literature, the efficient degradation of organic pollutants is generally attributed to the generation of active species, such as $\mathrm{SO}_{4}^{\bullet-}, \mathrm{HO}^{\bullet}$, ${ }^{1} \mathrm{O}_{2}$. The activation mechanisms of PMS by Mn(III) (oxyhydr)oxides are proposed, as shown in Figure 2. The simultaneous formation of $\mathrm{Mn}(\mathrm{II})$ and $\mathrm{Mn}(\mathrm{IV})$ and the conversion of Mn ions with different oxidation states explained well the good performance of Mn(III) (oxyhydr)oxides on PMS activation (Equations (1)-(4)) [44]. Except for the abovementioned processes, the direct generation of $\mathrm{HO}^{\bullet}$ by $\mathrm{Mn}$ (III) activation of PMS was also reported by some researchers (Equation (5)) $[62,64,66,68-70]$. In comparison with $\mathrm{SO}_{4}^{\bullet-}$ radical, the $\mathrm{SO}_{5}^{--}$radical has been regarded as a low oxidative activity for organic pollutants removal due to its low reduction potential $\left(\mathrm{E}_{0}=1.10 \mathrm{~V}\right.$ vs. NHE) [71]. Nevertheless, the transformation from $\mathrm{SO}_{5}^{--}$to $\mathrm{SO}_{4}^{--}$in $\mathrm{Mn}(\mathrm{III})$ (oxyhydr)oxides/PMS system still makes 
some contribution to the degradation of organic pollutants (Equation (6)) [72]. In addition, the conversion from $\mathrm{SO}_{4}^{\bullet-}$ to $\mathrm{HO}^{\bullet}$ in water should not be neglected (Equation (7)), especially, when the solution is in the alkaline environment (Equation (8)) [73].

$$
\begin{gathered}
\mathrm{Mn}(\mathrm{III})+\mathrm{HSO}_{5}^{-} \rightarrow \mathrm{Mn}(\mathrm{IV})+\mathrm{SO}_{4}^{\bullet-}+\mathrm{OH}^{-} \\
\mathrm{Mn}(\mathrm{III})+\mathrm{HSO}_{5}^{-} \rightarrow \mathrm{Mn}(\mathrm{II})+\mathrm{SO}_{5}^{\bullet-}+\mathrm{H}^{+} \\
\mathrm{Mn}(\mathrm{II})+\mathrm{HSO}_{5}^{-} \rightarrow \mathrm{Mn}(\mathrm{III})+\mathrm{SO}_{4}^{\bullet-}+\mathrm{OH}^{-} \\
\mathrm{Mn}(\mathrm{IV})+\mathrm{HSO}_{5}^{-} \rightarrow \mathrm{Mn}(\mathrm{III})+\mathrm{SO}_{5}^{\bullet-}+\mathrm{H}^{+} \\
\mathrm{Mn}(\mathrm{III})+\mathrm{HSO}_{5}^{-} \rightarrow \mathrm{Mn}(\mathrm{IV})+\mathrm{SO}_{4}^{2-}+\mathrm{HO}^{\bullet} \\
\mathrm{SO}_{5}^{\bullet-}+\mathrm{SO}_{5}^{\bullet-} \rightarrow \mathrm{O}_{2}+2 \mathrm{SO}_{4}^{\bullet-} \\
\mathrm{SO}_{4}^{\bullet-}+\mathrm{H}_{2} \mathrm{O} \rightarrow \mathrm{SO}_{4}^{2-}+\mathrm{HO}^{\bullet}+\mathrm{H}^{+} \\
\mathrm{SO}_{4}^{\bullet-}+\mathrm{OH}^{-} \rightarrow \mathrm{SO}_{4}^{2-}+\mathrm{HO}^{\bullet}
\end{gathered}
$$

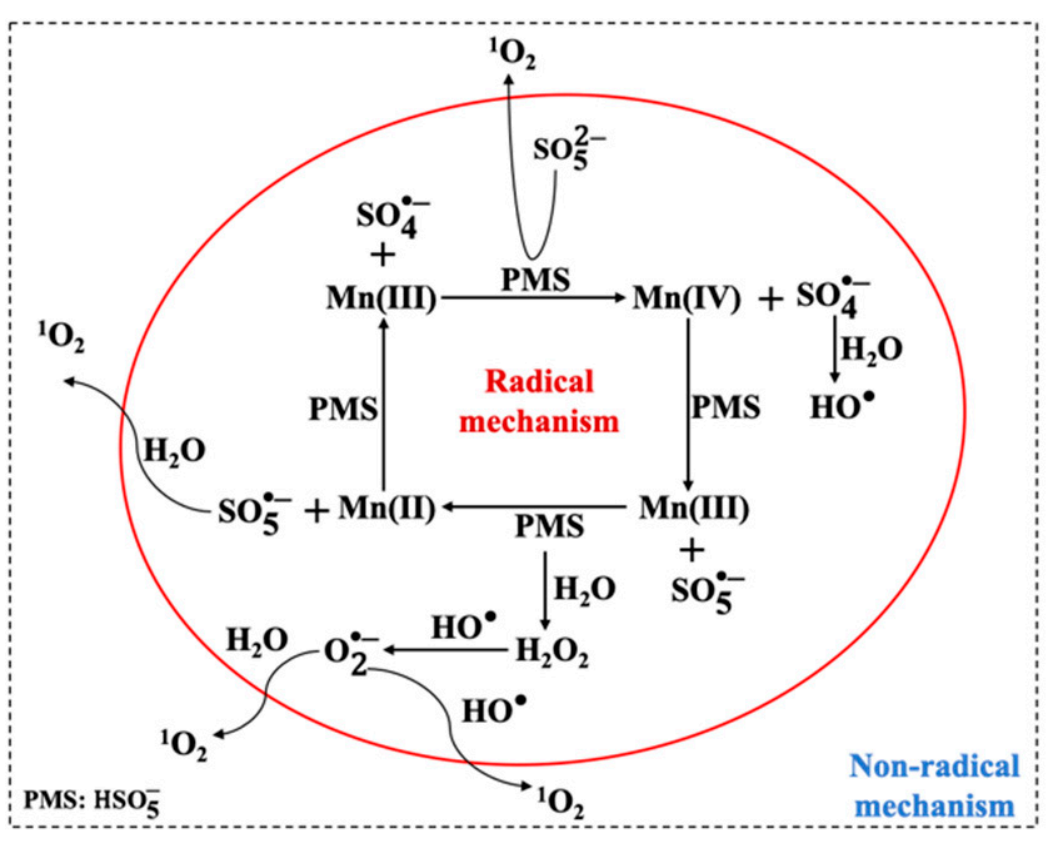

Figure 2. The activation mechanisms of peroxymonosulfate by $\mathrm{Mn}(\mathrm{III})$ (oxyhydr)oxides.

In addition to the active radicals, the generation of non-radical species (such as ${ }^{1} \mathrm{O}_{2}$ ) in the $\mathrm{Mn}$ (III) (oxyhydr)oxides-activated PMS system was also reported. For example, He et al. demonstrated the contribution of ${ }^{1} \mathrm{O}_{2}$ for the degradation of 2,4-dichlorophenol in the $\gamma-\mathrm{MnOOH} / \mathrm{PMS}$ system. The generation of ${ }^{1} \mathrm{O}_{2}$ was attributed to two pathways including the decomposition of PMS and the reaction of $\mathrm{O}_{2}^{\bullet-}$ with $\mathrm{HO}^{\bullet}$ (Equations (9) and (10)) $[59,74,75]$. Chen et al. synthesized one new $\mathrm{Mn}_{3} \mathrm{O}_{4}$ nanodots- $\mathrm{g}-\mathrm{C}_{3} \mathrm{~N}_{4}$ nanosheet $\left(\mathrm{Mn}_{3} \mathrm{O}_{4} / \mathrm{CNNS}\right)$ and investigated its performance on PMS activation for 4-chlorophenol (4-CP) degradation [76]. The chemical scavenging tests and electron spin resonance (ESR) experiments confirmed the contribution of ${ }^{1} \mathrm{O}_{2}$ for the removal of 4-CP. Furthermore, new pathways for the formation of ${ }^{1} \mathrm{O}_{2}$ were reported in the $\mathrm{Mn}_{3} \mathrm{O}_{4} / \mathrm{CNNS} / \mathrm{PMS}$ system. As shown in Equations (11)-(16), the reaction between $\mathrm{SO}_{5}^{\bullet-}$ and $\mathrm{H}_{2} \mathrm{O}$ and the combination of $\mathrm{O}_{2}^{\bullet-}$ with $\mathrm{H}_{2} \mathrm{O}$ can contribute to the formation of ${ }^{1} \mathrm{O}_{2}$ [76].

$$
\begin{gathered}
\mathrm{HSO}_{5}^{-}+\mathrm{SO}_{5}^{2-} \rightarrow \mathrm{HSO}_{4}^{-}+\mathrm{SO}_{4}^{2-}+{ }^{1} \mathrm{O}_{2} \\
\mathrm{O}_{2}^{\bullet-}+\mathrm{HO}^{\bullet} \rightarrow{ }^{1} \mathrm{O}_{2}+\mathrm{OH}^{-}
\end{gathered}
$$




$$
\begin{gathered}
2 \mathrm{SO}_{5}^{\bullet-}+\mathrm{H}_{2} \mathrm{O} \rightarrow 2 \mathrm{HSO}_{4}^{-}+1.5^{1} \mathrm{O}_{2} \\
\mathrm{HSO}_{5}^{-}+\mathrm{H}_{2} \mathrm{O} \rightarrow \mathrm{HSO}_{4}^{-}+\mathrm{H}_{2} \mathrm{O}_{2} \\
\mathrm{H}_{2} \mathrm{O}_{2} \rightarrow \mathrm{H}^{+}+\mathrm{HO}_{2}^{-} \mathrm{pKa}=11.6 \\
\mathrm{H}_{2} \mathrm{O}_{2}+\mathrm{HO}^{\bullet} \rightarrow \mathrm{H}_{2} \mathrm{O}+\mathrm{HO}_{2}^{\bullet} \\
\mathrm{HO}_{2}^{\bullet} \rightarrow \mathrm{H}^{+}+\mathrm{O}_{2}^{\bullet-} \mathrm{pKa}=4.88 \\
2 \mathrm{O}_{2}^{\bullet-}+2 \mathrm{H}_{2} \mathrm{O} \rightarrow \mathrm{H}_{2} \mathrm{O}_{2}+{ }^{1} \mathrm{O}_{2}+2 \mathrm{OH}^{-}
\end{gathered}
$$

Currently, the Mn-based oxide composites have attracted increasing attention due to their various advantages, such as more oxygen vacancies, higher surface oxygen mobility, and enforced synergistic effects. For instance, Chen et al. prepared the $\mathrm{Fe}_{2} \mathrm{O}_{3} / \mathrm{Mn}_{2} \mathrm{O}_{3}$ composite and studied its activity on PMS activation for tartrazine (TTZ) degradation. The results showed that $97.3 \%$ removal of TTZ was achieved in $30 \mathrm{~min}$ in the $\mathrm{Fe}_{2} \mathrm{O}_{3} / \mathrm{Mn}_{2} \mathrm{O}_{3} / \mathrm{PMS}$ system. The efficient degradation of TTZ originated from the generation of active species (e.g., $\mathrm{SO}_{4}^{\bullet-}, \mathrm{HO}^{\bullet}$ ) and the synergistic effect between iron and manganese ions [77]. The $\gamma$-MnOOH-coated nylon membrane was synthesized and applied in the activation of PMS towards the removal of 2,4-dichlorophenol (2,4-DCP). The deep removal of 2,4-DCP was explained by the synergetic "trap-and-zap" process, which improved the stability and

\begin{tabular}{|c|c|c|c|c|c|}
\hline Catalysts & Pollutant & Initial Conditions & Reactivity & Active Species & Ref. \\
\hline $\mathrm{Mn}_{2} \mathrm{O}_{3}$ & Phenol & $\begin{array}{c}{[\text { Catalyst }]=0.4 \mathrm{~g} / \mathrm{L}} \\
{[\mathrm{PMS}]=2 \mathrm{~g} / \mathrm{L}} \\
{[\text { Phenol] }=25 \mathrm{mg} / \mathrm{L}}\end{array}$ & $\begin{array}{l}100 \% \text { removal of } \\
\text { phenol in } 60 \mathrm{~min}\end{array}$ & $\mathrm{SO}_{4}^{\bullet-}$ & [44] \\
\hline $\mathrm{Mn}_{3} \mathrm{O}_{4}$ & Phenol & $\begin{array}{c}{[\text { Catalyst }]=0.4 \mathrm{~g} / \mathrm{L}} \\
{[\text { PMS }]=2 \mathrm{~g} / \mathrm{L}} \\
{[\text { Phenol] }=25 \mathrm{mg} / \mathrm{L}}\end{array}$ & $\begin{array}{l}100 \% \text { removal of } \\
\text { phenol in } 20 \mathrm{~min}\end{array}$ & $\mathrm{SO}_{4}^{\bullet-}$ & [78] \\
\hline $\begin{array}{c}\mathrm{Mn}_{3} \mathrm{O}_{4} \\
\text { nanoparticle }\end{array}$ & $\begin{array}{l}\text { Methylene blue } \\
\text { (MB) }\end{array}$ & $\begin{array}{c}\text { [Catalyst] = } 0.12 \mathrm{~g} / \mathrm{L} ; \\
{[\mathrm{PMS}]=0.94 \mathrm{~g} / \mathrm{L}} \\
{[\mathrm{MB}]=62 \mathrm{mg} / \mathrm{L}} \\
\mathrm{pH}=4\end{array}$ & $\begin{array}{l}86.71 \% \text { removal of } \\
\text { MB in } 20 \mathrm{~min}\end{array}$ & $\mathrm{SO}_{4}^{\bullet-}$ & [64] \\
\hline $\begin{array}{c}\mathrm{Mn}_{3} \mathrm{O}_{4} \\
\text { nano-octahedral }\end{array}$ & $\begin{array}{l}\text { Ciprofloxacin } \\
\text { (CIP) }\end{array}$ & $\begin{array}{c}\text { [Catalyst] = 0.2 g/L; } \\
{[\text { PMS }]=0.65 \mathrm{mM}} \\
{[\mathrm{CIP}]=10 \mathrm{mg} / \mathrm{L}} \\
\mathrm{pH}=7.7\end{array}$ & $\begin{array}{l}100 \% \text { removal of } \\
\mathrm{CIP} \text { in } 80 \mathrm{~min}\end{array}$ & $\begin{array}{l}\mathrm{SO}_{4}^{\bullet-} \\
\mathrm{HO}^{\bullet}\end{array}$ & [62] \\
\hline yolk-shell $\mathrm{Mn}_{3} \mathrm{O}_{4}$ & $\begin{array}{l}\text { Bisphenol A } \\
\text { (BPA) }\end{array}$ & $\begin{array}{c}\text { [Catalyst] }=0.1 \mathrm{~g} / \mathrm{L} \\
{[\mathrm{PMS}]=0.3 \mathrm{~g} / \mathrm{L}} \\
{[\mathrm{BPA}]=10 \mathrm{mg} / \mathrm{L}} \\
\mathrm{pH}=5.3\end{array}$ & $\begin{array}{l}87.7 \% \text { of removal } \\
\text { of BPA in } 60 \mathrm{~min}\end{array}$ & $\begin{array}{l}\mathrm{SO}_{4}^{\bullet-} \\
\mathrm{HO}^{\bullet}\end{array}$ & [67] \\
\hline $\begin{array}{c}\text { 3D hierarchical } \\
\mathrm{Mn}_{3} \mathrm{O}_{4}\end{array}$ & Phenol & $\begin{array}{c}\text { [Catalyst }]=0.2 \mathrm{~g} / \mathrm{L} \\
{[\text { PMS }]=6.5 \mathrm{mM}} \\
{[\text { Phenol] }=20 \mathrm{ppm}} \\
\mathrm{pH}=6.8\end{array}$ & $\begin{array}{l}100 \% \text { removal of } \\
\text { phenol in } 60 \mathrm{~min}\end{array}$ & $\begin{array}{l}\mathrm{SO}_{4}^{\bullet-} \\
\mathrm{HO}^{\bullet}\end{array}$ & [66] \\
\hline $\begin{array}{l}\text { dumbbell-like } \\
\mathrm{Mn}_{2} \mathrm{O}_{3}\end{array}$ & $\begin{array}{l}\text { Rhodamine B } \\
\quad(\mathrm{RhB})\end{array}$ & $\begin{array}{c}{[\text { Catalyst }]=0.25 \mathrm{~g} / \mathrm{L} ;} \\
{[\mathrm{PMS}]=0.75 \mathrm{~g} / \mathrm{L} ;} \\
{[\mathrm{RhB}]=10 \mathrm{mg} / \mathrm{L} ;}\end{array}$ & $\begin{array}{l}100 \% \text { of removal of } \\
\text { RhB in } 30 \mathrm{~min}\end{array}$ & $\begin{array}{l}\mathrm{SO}_{4}^{\bullet-} \\
\mathrm{HO}^{\bullet} \\
\mathrm{O}_{2}^{\bullet-} \\
{ }^{1} \mathrm{O}_{2}\end{array}$ & [65] \\
\hline
\end{tabular}
catalytic reactivity of $\gamma-\mathrm{MnOOH}$ [63]. In conclusion, the activation of PMS by $\mathrm{Mn}(\mathrm{III})$ (oxyhydr)oxides, including pure Mn(III) oxides and Mn(III) containing composites, is favorable. The degradation of various pollutants in the Mn(III) (oxyhydr)oxides/PMS system can be achieved through the generation of active radicals and non-radical species.

Table 3. Summary of PMS activation by Mn(III) (oxyhydr)oxides. 
Table 3. Cont.

\begin{tabular}{|c|c|c|c|c|c|}
\hline Catalysts & Pollutant & Initial Conditions & Reactivity & Active Species & Ref. \\
\hline$\alpha-\mathrm{Mn}_{2} \mathrm{O}_{3}$-cubic & Phenol & $\begin{array}{c}{[\text { Catalyst }]=0.4 \mathrm{~g} / \mathrm{L}} \\
{[\mathrm{PMS}]=2 \mathrm{~g} / \mathrm{L}} \\
{[\text { Phenol }]=25 \mathrm{ppm}}\end{array}$ & $\begin{array}{c}100 \% \text { removal of } \\
\text { phenol in } 1 \mathrm{~h}\end{array}$ & $\mathrm{SO}_{4}^{\bullet-}$ & [55] \\
\hline $\begin{array}{c}\gamma \text {-MnOOH } \\
\text { nanowire }\end{array}$ & $\begin{array}{l}\text { 2,4-dichlorophenol } \\
(2,4-\mathrm{DCP})\end{array}$ & $\begin{array}{c}{[\text { Catalyst }]=0.3 \mathrm{~g} / \mathrm{L} ;} \\
{[\mathrm{PMS}]=12 \mathrm{mM}} \\
{[2,4-\mathrm{DCP}]=100 \mathrm{mg} / \mathrm{L}} \\
\mathrm{pH}=7\end{array}$ & $\begin{array}{l}98 \% \text { removal of } \\
2,4-\mathrm{DCP} \text { in } 6 \mathrm{~h}\end{array}$ & $\begin{array}{l}\mathrm{SO}_{4}^{\bullet-} \\
\mathrm{HO}^{\bullet} \\
\mathrm{O}_{2}^{\bullet-} \\
{ }^{1} \mathrm{O}_{2}\end{array}$ & [59] \\
\hline MnOOH@nylon & 2,4-DCP & $\begin{array}{c}\text { [Catalyst }]=0.76 ; \mathrm{mg} / \mathrm{cm} 2 \\
{[\text { PMS }]=138 \mathrm{mg} / \mathrm{L}} \\
{[2,4-\mathrm{DCP}]=25 \mathrm{mg} / \mathrm{L}} \\
\mathrm{pH}=6.0-6.4\end{array}$ & $\begin{array}{l}97.9 \% \text { removal of } \\
2,4-\mathrm{DCP} \text { in } 2 \mathrm{~h}\end{array}$ & $\begin{array}{c}\mathrm{SO}_{4}^{\bullet-} \\
\mathrm{HO}^{\bullet} \\
\mathrm{O}_{2}^{\bullet-} \\
{ }^{1} \mathrm{O}_{2} \\
\end{array}$ & [63] \\
\hline$\gamma$-MnOOH-rGO & Bentazone & $\begin{array}{c}\text { [Catalyst] = } 0.075 \mathrm{~g} / \mathrm{L} \\
{[\text { PMS }]=0.615 \mathrm{~g} / \mathrm{L} ;} \\
\text { [Bentazone] = } 10 \mathrm{mg} / \mathrm{L} \\
\text { pH = 7; sunlight; }\end{array}$ & $\begin{array}{l}\text { 96.1\% removal of } \\
\text { Bentazone in } 90 \\
\text { min }\end{array}$ & $\begin{array}{l}\mathrm{HO}^{\bullet} \\
{ }^{1} \mathrm{O}_{2}\end{array}$ & [79] \\
\hline $\mathrm{Ce}-\mathrm{Mn}_{2} \mathrm{O}_{3}$ & 2,4-DCP & $\begin{array}{c}{[\text { Catalyst }]=0.2 \mathrm{~g} / \mathrm{L}} \\
{[\mathrm{PMS}]=1.0 \mathrm{~g} / \mathrm{L}} \\
{[2,4-\mathrm{DCP}]=50 \mathrm{mg} / \mathrm{L}} \\
\mathrm{pH}=7\end{array}$ & $\begin{array}{l}100 \% \text { removal of } \\
2,4-\mathrm{DCP} \text { in } 90 \mathrm{~min}\end{array}$ & $\begin{array}{l}\mathrm{SO}_{4}^{\bullet-} \\
\mathrm{HO}^{\bullet} \\
{ }^{1} \mathrm{O}_{2}\end{array}$ & [80] \\
\hline $\mathrm{Mn}_{3} \mathrm{O}_{4}-\mathrm{GO}$ & Orange II & $\begin{array}{c}\text { [Catalyst] }=50 \mathrm{mg} / \mathrm{L} ; \\
{[\text { PMS }=1.5 \mathrm{~g} / \mathrm{L}} \\
{[\text { Orange II] }=30 \mathrm{mg} / \mathrm{L} ;} \\
\mathrm{pH}=7.0\end{array}$ & $\begin{array}{l}\text { 100\% removal of } \\
\text { Orange II in } 120 \\
\text { min }\end{array}$ & $\mathrm{SO}_{4}^{\bullet-}$ & [81] \\
\hline $\mathrm{Fe}_{2} \mathrm{O}_{3} / \mathrm{Mn}_{2} \mathrm{O}_{3}$ & $\begin{array}{l}\text { Tartrazine } \\
\text { (TTZ) }\end{array}$ & $\begin{array}{c}\text { [Catalyst }]=0.6 \mathrm{~g} / \mathrm{L} \\
{[\mathrm{PMS}]=0.8 \mathrm{~g} / \mathrm{L}} \\
{[\mathrm{TTZ}]=10 \mathrm{mg} / \mathrm{L}} \\
\mathrm{pH}=6.89\end{array}$ & $\begin{array}{l}97.3 \% \text { removal of } \\
\text { TTZ in } 30 \mathrm{~min}\end{array}$ & $\begin{array}{l}\mathrm{SO}_{4}^{\bullet-} \\
\mathrm{HO}^{\bullet}\end{array}$ & [77] \\
\hline $\mathrm{Mn}_{2} \mathrm{O}_{3} @ \mathrm{Mn}_{5} \mathrm{O}_{8}$ & $\begin{array}{l}\text { 4-chlorophenol } \\
\text { (4-CP) }\end{array}$ & $\begin{array}{c}{[\text { Catalyst }]=0.3 \mathrm{~g} / \mathrm{L} ;} \\
{[\mathrm{PMS}]=1.5 \mathrm{mM}} \\
{[4-\mathrm{CP}]=80 \mathrm{ppm}}\end{array}$ & $\begin{array}{l}100 \% \text { removal of } \\
4-C P \text { in } 60 \mathrm{~min}\end{array}$ & $\begin{array}{c}\mathrm{SO}_{4}^{\bullet-} \\
\mathrm{HO}^{\bullet} \\
\mathrm{O}_{2}^{\bullet-} \\
{ }^{1} \mathrm{O}_{2}\end{array}$ & [82] \\
\hline $\mathrm{Mn}_{3} \mathrm{O}_{4}-\mathrm{MnO}_{2}$ & CIP & $\begin{array}{c}\text { [Catalyst }]=0.1 \mathrm{~g} / \mathrm{L} ; \\
{[\mathrm{PMS}]=1 \mathrm{mM}} \\
{[\mathrm{CIP}]=50 \mu \mathrm{M} ;} \\
\mathrm{pH}=7.0 \pm 0.1\end{array}$ & $\begin{array}{l}97.6 \% \text { removal of } \\
\text { CIP in } 25 \mathrm{~min}\end{array}$ & $\begin{array}{l}\mathrm{SO}_{4}^{\bullet-} \\
\mathrm{HO}^{\bullet}\end{array}$ & [68] \\
\hline $\mathrm{Mn}_{3} \mathrm{O}_{4} / \mathrm{MOF}$ & RhB & $\begin{array}{c}\text { [Catalyst }]=0.4 \mathrm{~g} / \mathrm{L} \\
{[\mathrm{PMS}]=0.3 \mathrm{~g} / \mathrm{L}} \\
{[\mathrm{RhB}]=10 \mathrm{mg} / \mathrm{L}} \\
\mathrm{pH}=5.18\end{array}$ & $\begin{array}{l}98 \% \text { removal of } \\
\text { RhB in } 60 \mathrm{~min}\end{array}$ & $\begin{array}{l}\mathrm{SO}_{4}^{\bullet-} \\
\mathrm{HO}^{\bullet}\end{array}$ & [69] \\
\hline $\mathrm{Fe}_{3} \mathrm{O}_{4} / \mathrm{Mn}_{3} \mathrm{O}_{4} / \mathrm{GO}$ & $\mathrm{MB}$ & $\begin{array}{c}\text { [Catalyst] = } 100 \mathrm{mg} / \mathrm{L} \\
{[\mathrm{PMS}]=0.3 \mathrm{~g} / \mathrm{L}} \\
{[\mathrm{MB}]=50 \mathrm{mg} / \mathrm{L}} \\
\mathrm{pH}=7\end{array}$ & $\begin{array}{l}98.8 \% \text { removal of } \\
\mathrm{MB} \text { in } 30 \mathrm{~min}\end{array}$ & $\begin{array}{l}\mathrm{SO}_{4}^{\bullet-} \\
\mathrm{HO}^{\bullet}\end{array}$ & [83] \\
\hline $\begin{array}{c}\mathrm{Mn}_{3} \mathrm{O}_{4} / \mathrm{CNNS}- \\
150\end{array}$ & $4-\mathrm{CP}$ & $\begin{array}{c}\text { [Catalyst }]=0.3 \mathrm{~g} / \mathrm{L} \\
{[\mathrm{PMS}]=1 \mathrm{mM}} \\
{[4-\mathrm{CP}]=50 \mathrm{mg} / \mathrm{L}} \\
\mathrm{pH}=6.89\end{array}$ & $\begin{array}{l}100 \% \text { removal of } \\
4-\mathrm{CP} \text { in } 60 \mathrm{~min}\end{array}$ & ${ }^{1} \mathrm{O}_{2}$ & [76] \\
\hline $\begin{array}{c}\alpha-\mathrm{Mn}_{2} \mathrm{O}_{3} @ \alpha- \\
\mathrm{MnO}_{2}-350\end{array}$ & Phenol & $\begin{array}{c}\text { [Catalyst }]=0.4 \mathrm{~g} / \mathrm{L} ; \\
{[\text { PMS }]=2.0 \mathrm{~g} / \mathrm{L} ;} \\
{[\text { Phenol }]=25 \mathrm{mg} / \mathrm{L} ;} \\
\text { pH = 3-3.5; }\end{array}$ & $\begin{array}{l}100 \% \text { removal of } \\
\text { phenol in } 25 \mathrm{~min}\end{array}$ & $\begin{array}{l}\mathrm{SO}_{4}^{\bullet-} \\
\mathrm{HO}^{\bullet}\end{array}$ & [84] \\
\hline
\end{tabular}


Table 3. Cont.

\begin{tabular}{|c|c|c|c|c|c|}
\hline Catalysts & Pollutant & Initial Conditions & Reactivity & Active Species & Ref. \\
\hline $\begin{array}{c}\alpha-\mathrm{Mn}_{2} \mathrm{O}_{3} @ \alpha- \\
\mathrm{MnO}_{2}-500\end{array}$ & Phenol & $\begin{aligned} {[\text { Catalyst }] } & =0.15 \mathrm{~g} / \mathrm{L} ; \\
{[\mathrm{PMS}] } & =1 \mathrm{mM} ; \\
{[\text { Phenol }] } & =25 \mathrm{ppm} ;\end{aligned}$ & $\begin{array}{l}100 \% \text { removal of } \\
\text { phenol in } 70 \mathrm{~min}\end{array}$ & $\begin{array}{c}\mathrm{SO}_{4}^{\bullet-} \\
\mathrm{HO}^{\bullet} \\
{ }^{1} \mathrm{O}_{2}\end{array}$ & [85] \\
\hline $\mathrm{CuS} / \mathrm{Fe}_{2} \mathrm{O}_{3} / \mathrm{Mn}_{2} \mathrm{O}_{3}$ & CIP & $\begin{array}{c}\text { [Catalyst] = } 0.6 \mathrm{~g} / \mathrm{L} \\
{[\mathrm{PMS}]=0.6 \mathrm{~g} / \mathrm{L}} \\
{[\mathrm{CIP}]=10 \mathrm{mg} / \mathrm{L}} \\
\mathrm{pH}=5.84\end{array}$ & $\begin{array}{l}88 \% \text { removal of } \\
\mathrm{CIP} \text { in } 120 \mathrm{~min}\end{array}$ & $\begin{array}{l}\mathrm{SO}_{4}^{\bullet-} \\
\mathrm{HO}^{\bullet}\end{array}$ & [86] \\
\hline
\end{tabular}

\subsection{Activation of PDS by Mn(III) (Oxyhydr)Oxides}

Single or combined Mn(III) (oxyhydr)oxides have been employed to activate PDS to remove different organic pollutants, such as phenol, p-chloroaniline (PCA), 2,4-dichlorophenol $(2,4-\mathrm{DCP})$, and organic dyes (Table 4). The activation pathway of PDS varies with the different types of Mn(III) (oxyhydr)oxides (Figure 3). For example, Shabanloo et al. reported the generation of active $\mathrm{SO}_{4}^{--}$radicals in the nano- $\mathrm{Mn}_{3} \mathrm{O}_{4} / \mathrm{PDS}$ system [87]. Since both $\mathrm{Mn}(\mathrm{II})$ and $\mathrm{Mn}$ (III) species are identified in the $\mathrm{Mn}_{3} \mathrm{O}_{4}$ structure, the formation of $\mathrm{SO}_{4}^{\circ-}$ was mainly attributed to the activation of PDS by $\mathrm{Mn}$ (II) (Equation (17)). In contrast, the persulfate radical $\left(\mathrm{S}_{2} \mathrm{O}_{8}^{\bullet-}\right)$ was produced by the reaction of PDS and $\mathrm{Mn}$ (III) (Equation (18)). For the system of $\mathrm{Mn}_{2} \mathrm{O}_{3} / \mathrm{PDS}$, it is believed that the singlet oxygen $\left({ }^{1} \mathrm{O}_{2}\right)$ was the primary active species that was responsible for the degradation of organic pollutants [88]. As demonstrated by Khan et al., one complex $\equiv \mathrm{Mn}(\mathrm{III} / \mathrm{IV})-\mathrm{OS}_{2} \mathrm{O}_{7}^{-}$was formed between PDS and $\mathrm{Mn}_{2} \mathrm{O}_{3}$ through the inner-sphere interaction. Then, another $\mathrm{S}_{2} \mathrm{O}_{8}^{2-}$ was decomposed by $\equiv \mathrm{Mn}(\mathrm{III} / \mathrm{IV})-\mathrm{OS}_{2} \mathrm{O}_{7}^{-}$to generate $\mathrm{HO}_{2}^{*} / \mathrm{O}_{2}^{\bullet-}$ radicals. The ${ }^{1} \mathrm{O}_{2}$ was finally formed from the direct oxidation of $\mathrm{O}_{2}^{\bullet-}$ by $\equiv \mathrm{Mn}(\mathrm{IV})-\mathrm{OS}_{2} \mathrm{O}_{7}^{-}$or the recombination of $\mathrm{HO}_{2}^{\bullet}$ and $\mathrm{O}_{2}^{\bullet-}$ (Equations (19)-(20)). The pathway of ${ }^{1} \mathrm{O}_{2}$ formation in the system of $\mathrm{A}-\mathrm{Mn}_{2} \mathrm{O}_{3} / \mathrm{PDS}$ is comparable to the approach of producing ${ }^{1} \mathrm{O}_{2}$ in the $\beta-\mathrm{MnO}_{2} / \mathrm{PDS}$ system in which the important metastable manganese intermediate was first formed through the complex reaction between the hydroxyl group $(-\mathrm{OH})$ and cleavaged $\mathrm{S}_{2} \mathrm{O}_{8}^{2-}$ [41]. Therefore, the hydroxyl group on the surface of manganese oxides plays a significant role in PDS activation.

$$
\begin{gathered}
\equiv \mathrm{Mn}(\mathrm{II})+\mathrm{S}_{2} \mathrm{O}_{8}^{2-} \rightarrow \equiv \mathrm{Mn}(\mathrm{III})+\mathrm{SO}_{4}^{\bullet-}+\mathrm{SO}_{4}^{2-} . \\
\equiv \mathrm{Mn}(\mathrm{III})+\mathrm{S}_{2} \mathrm{O}_{8}^{2-} \rightarrow \equiv \mathrm{Mn}(\mathrm{II})+\mathrm{S}_{2} \mathrm{O}_{8}^{\bullet-} \\
\equiv \mathrm{Mn}(\mathrm{IV})-\mathrm{OS}_{2} \mathrm{O}_{7}^{-}+\mathrm{O}_{2}^{\bullet-}+\mathrm{OH}^{-} \rightarrow \equiv \mathrm{Mn}(\mathrm{III})-\mathrm{OH}^{-}+2 \mathrm{SO}_{4}^{2-}+{ }^{1} \mathrm{O}_{2} \\
\mathrm{O}_{2}^{\bullet-}+\mathrm{HO}_{2}^{\bullet} \rightarrow{ }^{1} \mathrm{O}_{2}+\mathrm{HO}_{2}^{-}
\end{gathered}
$$

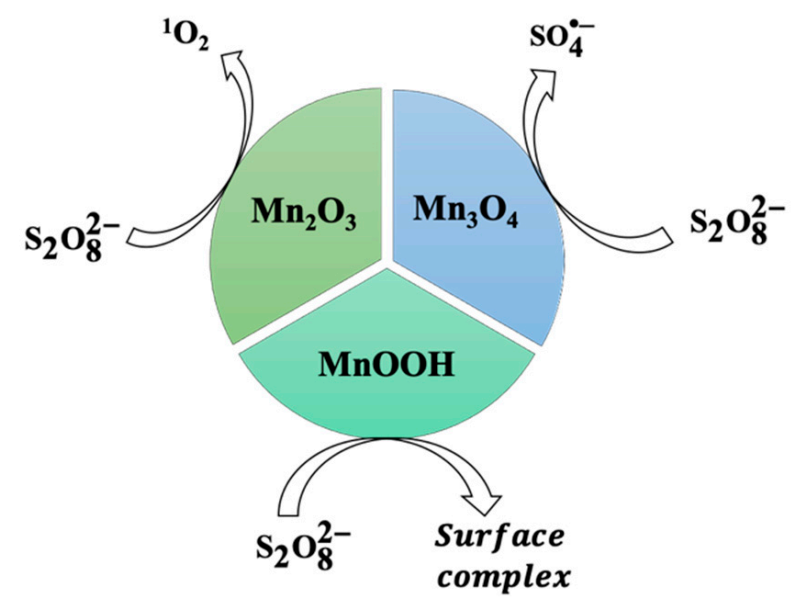

Figure 3. The activation mechanisms of peroxydisulfate by various Mn(III) (oxyhydr)oxides. 
In comparison with $\mathrm{Mn}_{3} \mathrm{O}_{4}$ and $\mathrm{Mn}_{2} \mathrm{O}_{3}, \gamma-\mathrm{MnOOH}$ presents more $-\mathrm{OH}$ groups on the surface, leading to the high efficiency in PDS activation. For instance, Li et al. reported that $\gamma-\mathrm{MnOOH}$ exhibited higher reactivity in PDS activation for phenol oxidation in comparison with $\mathrm{Mn}_{2} \mathrm{O}_{3}$ and $\mathrm{Mn}_{3} \mathrm{O}_{4}$ [89]. The authors reported that the degradation efficiency of phenol in the $\gamma$-MnOOH/PDS system was $\mathrm{pH}$-dependent. Under the basic condition ( $\mathrm{pH} 11$ ), phenol was efficiently removed due to the generation of $\mathrm{SO}_{4}^{\bullet-}$ and $\mathrm{HO}^{\bullet}$ radicals. However, at $\mathrm{pH} 3$ and 7 , the oxidative intermediate $\left(\equiv \mathrm{Mn}(\mathrm{III})-{ }_{3}^{-} \mathrm{OSOOSO}_{3}^{-}\right)$ was believed to be responsible for the removal of phenol. Although the mentioned report explained well the oxidation performance of $\gamma-\mathrm{MnOOH} / \mathrm{PMS}$ for phenol removal, the information regarding the mechanism of PDS activation on the surface of $\gamma-\mathrm{MnOOH}$ was not given in detail. Considering this, $\mathrm{Xu}$ et al. conducted a further investigation focusing on the catalytic mechanism of PDS by $\gamma-\mathrm{MnOOH}$ [90]. Based on the results of chemical scavenging and ESR experiments, a non-radical mechanism was proposed. Generally, the non-radical mechanism in PS activation was attributed to three aspects-the generation of ${ }^{1} \mathrm{O}_{2}$, the electron transfer process, and the catalyst surface-activated intermediates [91-95]. However, the ${ }^{1} \mathrm{O}_{2}$ production and electron transfer process mechanism were excluded according to the results of ESR and linear sweep voltammetry (LSV) experiments. Therefore, the $\gamma$-MnOOH surface-activated PDS molecules were verified as the main active species for the degradation of PCA. Figure 4 shows the formation of active PDS molecules on the surface of $\gamma-\mathrm{MnOOH}$.

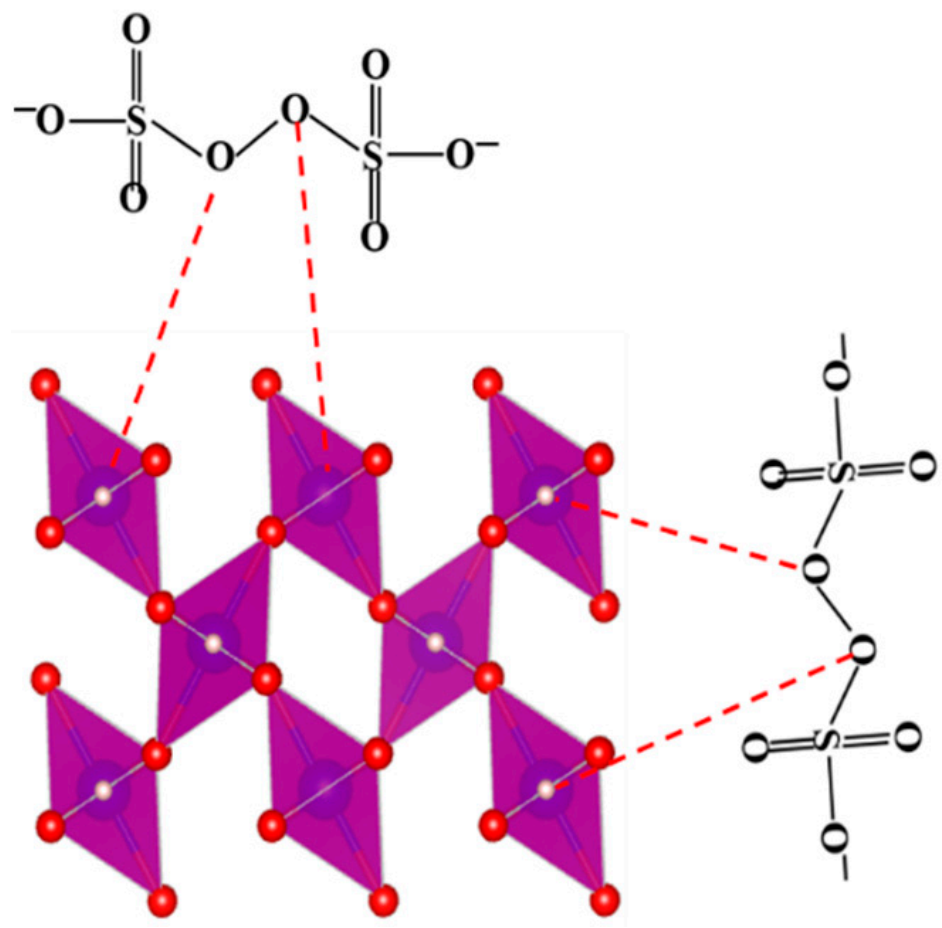

Figure 4. The diagram of PDS activation on the surface of $\gamma-\mathrm{MnOOH}$. The red, blue, and white balls in the structure of $\gamma-\mathrm{MnOOH}$ represent the oxygen, manganese, and hydrogen atoms, respectively. The COD ID of $\gamma-\mathrm{MnOOH}$ is 1011012 [54].

The activation of PDS by Mn(III) (oxyhydr)oxide composites for pollutant degradation was also reported [96-98]. For instance, Liu et al. synthesized the carbon-coated $\mathrm{Mn}_{3} \mathrm{O}_{4}$ composite $\left(\mathrm{Mn}_{3} \mathrm{O}_{4} / \mathrm{C}\right)$ and investigated the reactivity in the presence of PDS for 2,4-dichlorophenol (2,4-DCP) degradation [96]. The results showed that 95\% of 2,4-DCP removal was reached in $140 \mathrm{~min}$ and the enhanced degradation was attributed to the existence of the defective edges of the carbon layer, which facilitated the attraction and activation of PDS. Rizal et al. prepared $\mathrm{Ag} / \mathrm{Mn}_{3} \mathrm{O}_{4}$ and $\mathrm{Ag} / \mathrm{Mn}_{3} \mathrm{O}_{4} /$ graphene composites and studied the degradation efficiency of methylene blue (MB) by the synthesized catalysts 
activated PDS in the presence of visible light [97]. The results showed that $40 \mathrm{mg} / \mathrm{L}$ of MB was completely removed in $30 \mathrm{~min}$ by the system of $\mathrm{Ag} / \mathrm{Mn}_{3} \mathrm{O}_{4} /$ graphene + PDS under visible light. The enhanced degradation of $\mathrm{MB}$ was attributed to the hampered electron-hole recombination due to the loading of $\mathrm{Ag}$ and graphene. Furthermore, the studies regarding the application of modified $\mathrm{Mn}_{2} \mathrm{O}_{3}$ in oxidants (such as PMS, $\mathrm{H}_{2} \mathrm{O}_{2}$ ) activation for contaminants removal were also reported [84,99-101]. For example, Saputra et al. prepared an egg-shaped core/shell $\alpha-\mathrm{Mn}_{2} \mathrm{O}_{3} @ \alpha-\mathrm{MnO}_{2}$ catalyst via a hydrothermal process and investigated the catalytic activity of $\alpha-\mathrm{Mn}_{2} \mathrm{O}_{3} @ \alpha-\mathrm{MnO}_{2}$ in heterogeneous Oxone ${ }^{\circledR}$ activation for phenol degradation [84]. The loaded $\alpha-\mathrm{MnO}_{2}$ improved the generation of $\mathrm{Mn}$ (III) species through the reaction with PMS. The amount of $\mathrm{SO}_{4}^{--}$and $\mathrm{HO}^{\bullet}$ was then increased leading to the enhanced degradation of phenol. The efficient degradation of organic dye pollutants (such as Rhodamine B (RhB) and Congo Red (CR)) by bimetallic $\mathrm{Mn}_{2} \mathrm{O}_{3}-\mathrm{Co}_{3} \mathrm{O}_{4} /$ carbon catalyst activated Fenton-like reaction was also reported [100]. The superior reactivity of $\mathrm{Mn}_{2} \mathrm{O}_{3}-\mathrm{Co}_{3} \mathrm{O}_{4} / \mathrm{C}$ catalyst in $\mathrm{H}_{2} \mathrm{O}_{2}$ activation for $\mathrm{RB}$ and $\mathrm{CR}$ degradation was attributed to the good synergistic effect between $\mathrm{Co}_{3} \mathrm{O}_{4}$ and $\mathrm{Mn}_{2} \mathrm{O}_{3}$ as well as the interaction between metal oxides and carbon. However, the investigation regarding the activation of PDS by modified $\alpha-\mathrm{Mn}_{2} \mathrm{O}_{3}$ has been less reported. The same effect was also observed for the $\gamma$-MnOOH-based composites. This might be attributed to the distinct activation way of PDS by $\alpha-\mathrm{Mn}_{2} \mathrm{O}_{3}$ or $\gamma-\mathrm{MnOOH}$ compared with $\mathrm{Mn}_{3} \mathrm{O}_{4}$.

In summary, $\mathrm{Mn}_{3} \mathrm{O}_{4}$ can activate $\mathrm{PDS}$ to generate $\mathrm{SO}_{4}^{\bullet-}$ through radical mechanisms, while the activation of PDS by $\alpha-\mathrm{Mn}_{2} \mathrm{O}_{3}$ and $\gamma-\mathrm{MnOOH}$ is processed in a non-radical mechanism with the generation of ${ }^{1} \mathrm{O}_{2}$ and catalyst surface-activated PDS substances. For the activation of PDS by $\mathrm{Mn}\left(\mathrm{III}\right.$ ) (oxyhydr)oxides composites, the $\mathrm{Mn}_{3} \mathrm{O}_{4}$-based composites have shown good catalytic performance in PDS activation for pollutant degradation. In comparison, the activation of PDS by modified $\alpha-\mathrm{Mn}_{2} \mathrm{O}_{3}$ or $\gamma-\mathrm{MnOOH}$ catalysts needs to be further investigated.

Table 4. Summary of PDS activation by Mn(III) (oxyhydr)oxides.

\begin{tabular}{|c|c|c|c|c|c|}
\hline Catalysts & Pollutant & Initial Conditions & Reactivity & Active Species & Ref. \\
\hline$\gamma-\mathrm{MnOOH}$ & $\begin{array}{l}\text { P-chloroaniline } \\
\text { (PCA) }\end{array}$ & $\begin{array}{c}\text { [Catalyst }]=0.4 \mathrm{~g} / \mathrm{L} \\
{[\text { PDS }]=2.5 \mathrm{mM}} \\
{[\text { PCA }]=0.5 \mathrm{mM}} \\
\mathrm{pH}=4.2\end{array}$ & $\begin{array}{l}100 \% \text { removal of } \\
\text { PCA in } 180 \mathrm{~min}\end{array}$ & $\begin{array}{c}\gamma \text {-MnOOH-PDS } \\
\text { complex }\end{array}$ & [90] \\
\hline $\mathrm{A}-\mathrm{Mn}_{2} \mathrm{O}_{3}$ & Phenol & $\begin{array}{c}\text { [Catalyst }]=0.2 \mathrm{~g} / \mathrm{L} \\
{[\text { PDS }]=2 \mathrm{mM}} \\
{[\text { Phenol] }=12 \mathrm{ppm}} \\
\mathrm{pH}=3.2\end{array}$ & $\begin{array}{l}100 \% \text { removal of } \\
\text { phenol in } 70 \mathrm{~min}\end{array}$ & ${ }^{1} \mathrm{O}_{2}$ & [88] \\
\hline $\mathrm{Mn}_{3} \mathrm{O}_{4}$ nanoparticle & $\begin{array}{l}\text { Acid Blue } 113 \\
\quad \text { (AB113) }\end{array}$ & $\begin{array}{c}\text { [Catalyst] }=57.69 \mathrm{mg} / \mathrm{L} ; \\
{[\text { PDS }]=61.46 \mathrm{mg} / \mathrm{L} ;} \\
{[\text { AB113] }=50 \mathrm{mg} / \mathrm{L} ;} \\
\mathrm{pH}=3 ;\end{array}$ & $\begin{array}{l}96.7 \% \text { removal of } \\
\text { AB113 in } 60 \mathrm{~min}\end{array}$ & $\begin{array}{l}\mathrm{SO}_{4}^{\bullet-} \\
\mathrm{HO}^{\bullet}\end{array}$ & [102] \\
\hline$\gamma-\mathrm{MnOOH}$ & Phenol & $\begin{array}{c}\text { [Catalyst] }=1 \mathrm{~g} / \mathrm{L} \\
{[\text { PDS }]=2 \mathrm{~g} / \mathrm{L}} \\
{[\text { Phenol] }=100 \mathrm{mg} / \mathrm{L}} \\
\text { pH = }\end{array}$ & $\begin{array}{l}91.86 \% \text { removal of } \\
\text { phenol in } 360 \mathrm{~min}\end{array}$ & $\begin{array}{c}\gamma \text {-MnOOH-PDS } \\
\text { complex }\end{array}$ & [89] \\
\hline Nano- $\mathrm{Mn}_{3} \mathrm{O}_{4}$ & Furfural & $\begin{array}{c}\text { [Catalyst] }=1.2 \mathrm{~g} / \mathrm{L} \\
{[\text { PDS] }=6.34 \mathrm{mM}} \\
\text { [Furfural] }=50 \mathrm{mg} / \mathrm{L} \\
\mathrm{pH}=4.82\end{array}$ & $\begin{array}{l}91.14 \% \text { of furfural } \\
\text { removal in } 60 \mathrm{~min}\end{array}$ & $\mathrm{SO}_{4}^{\bullet-}$ & [87] \\
\hline $\mathrm{Ag} / \mathrm{Mn}_{3} \mathrm{O}_{4}-5 \mathrm{G}$ & $\mathrm{MB}$ & $\begin{array}{c}\text { [Catalyst] = } 0.5 \mathrm{~g} / \mathrm{L} \\
{[\mathrm{PDS}]=12 \mathrm{mM}} \\
{[\mathrm{MB}]=40 \mathrm{mg} / \mathrm{L}} \\
\mathrm{pH}=3 \\
\text { visible-light; }\end{array}$ & $\begin{array}{l}100 \% \text { of } \mathrm{MB} \\
\text { removal in } 30 \mathrm{~min}\end{array}$ & $\begin{array}{l}\mathrm{SO}_{4}^{\bullet-} \\
\mathrm{HO}^{\bullet}\end{array}$ & [97] \\
\hline
\end{tabular}


Table 4. Cont.

\begin{tabular}{|c|c|c|c|c|c|}
\hline Catalysts & Pollutant & Initial Conditions & Reactivity & Active Species & Ref. \\
\hline $\begin{array}{c}\mathrm{Mn}_{2} \mathrm{O}_{3} / \mathrm{Mn}_{3} \mathrm{O}_{4} / \mathrm{MnO}_{2}- \\
10\end{array}$ & Orange II & $\begin{array}{c}\text { [Catalyst] }=0.4 \mathrm{~g} / \mathrm{L} ; \\
{[\mathrm{PDS}]=2 \mathrm{~g} / \mathrm{L} ;} \\
{[\text { Orange II] }=20 \mathrm{mg} / \mathrm{L} ;}\end{array}$ & $\begin{array}{l}95 \% \text { removal of } \\
\text { Orange II in } 50 \mathrm{~min}\end{array}$ & $\begin{array}{l}\mathrm{SO}_{4}^{\bullet-} \\
\mathrm{HO}^{\bullet}\end{array}$ & [103] \\
\hline $0.5-\mathrm{Mn}_{3} \mathrm{O}_{4} / \mathrm{C}-\mathrm{T} 4$ & 2,4-DCP & $\begin{array}{c}{[\text { Catalyst }]=0.2 \mathrm{~g} / \mathrm{L}} \\
{[\mathrm{PDS}]=2 \mathrm{~g} / \mathrm{L}} \\
{[2,4-\mathrm{DCP}]=100 \mathrm{mg} / \mathrm{L}} \\
\mathrm{pH}=6.37\end{array}$ & $\begin{array}{l}\text { 95\% removal of } \\
2,4-\mathrm{DCP} \text { in } 140 \mathrm{~min}\end{array}$ & $\begin{array}{l}\mathrm{SO}_{4}^{\bullet-} \\
\mathrm{HO}^{\bullet} \\
{ }^{1} \mathrm{O}_{2}\end{array}$ & [96] \\
\hline$\gamma-\mathrm{Fe}_{2} \mathrm{O}_{3} / \mathrm{Mn}_{3} \mathrm{O}_{4}$ & $\mathrm{RhB}$ & $\begin{array}{c}\text { [Catalyst] = } 50 \mathrm{mg} / \mathrm{L} \\
{[\mathrm{PDS}]=50 \mathrm{mg} / \mathrm{L} ;} \\
{[\mathrm{RhB}]=10 \mathrm{mg} / \mathrm{L}} \\
\mathrm{pH}=4.5\end{array}$ & $\begin{array}{l}97.5 \% \text { removal of } \\
\mathrm{RhB} \text { in } 150 \mathrm{~min}\end{array}$ & $\begin{array}{l}\mathrm{SO}_{4}^{\bullet-} \\
\mathrm{HO}^{\bullet}\end{array}$ & [98] \\
\hline
\end{tabular}

\section{Influence Factors for Mn(III) (Oxyhydr)Oxides Reactivity}

\subsection{The Effect of $p H$}

The Mn(III) (oxyhydr)oxides-mediated activation of PDS/PMS can be affected by solution $\mathrm{pH}$ in different ways. For example, influencing the property of charge on the surface of the catalysts, changing the ionic forms of PDS/PMS and pollutant molecules, as well as altering the reduction potential of active radicals.

First, the solution $\mathrm{pH}$ can affect the interaction between catalyst and PDS/PMS and pollutants through changing the electrostatic effect. The point of zero charges (PZC) of the catalyst and the acid dissociation constant $(\mathrm{pKa}$ ) of radical precursors and contaminants are two important parameters that are used to recognize the charge type on the surface of the catalysts and the ionic situation of oxidants and pollutants in solution. For instance, when the solution $\mathrm{pH}$ is equal to the PZC value of the catalyst, the amounts of positive and negative charges on the surface of the catalyst are equal (i.e., the surface charge of the catalyst is zero). When the solution $\mathrm{pH}$ is higher than the $\mathrm{PZC}$ value of the catalyst, the surface charges of the catalyst are negative. On the contrary, if the solution $\mathrm{pH}$ is lower than the catalyst PZC value, the surface of the catalyst will be positively charged [104]. The same situation is suitable for the analysis of the ionic form of oxidants and pollutants. The PZC values of commonly used Mn(III) (oxyhydr)oxides and the pKa values of PMS/PDS, and some typical pollutants, are summarized in Table 5. The impacts of solution $\mathrm{pH}$ on the interaction between Mn(III) (oxyhydr)oxides and PDS/PMS and pollutants have been reported. For example, Zhao et al. reported that the adsorption and degradation of ciprofloxacin (CIP) by the synthesized $\mathrm{Mn}_{3} \mathrm{O}_{4}-\mathrm{MnO}_{2}$ composite were facilitated at neutral $\mathrm{pH}$ solution [68]. The results were explained by the enhanced electrostatic attraction between $\mathrm{Mn}_{3} \mathrm{O}_{4}-\mathrm{MnO}_{2}$ and CIP. The PZC value of the $\mathrm{Mn}_{3} \mathrm{O}_{4}-\mathrm{MnO}_{2}$ composite was measured at 2.5; thus, in the solution $\mathrm{pH} 7$, the surface of the catalyst was negatively charged. In comparison, the pKa of CIP was 8.7-10.58, leading to the formation of positively charged CIP ions in the neutral $\mathrm{pH}$ solution. Therefore, the electrostatic attraction between the negative catalyst and the positive CIP improved, resulting in a facilitating degradation of CIP. The same phenomenon was also reported in the studies of PDS activation by $\gamma-\mathrm{MnOOH} / \alpha-\mathrm{Mn}_{2} \mathrm{O}_{3}$ for pollutant degradation $[88,90]$.

Second, the transformation of radicals also influenced the reactivity of $\mathrm{Mn}$ (III) (oxyhydr)oxides for pollutant degradation. For instance, the reported conversion of $\mathrm{SO}_{4}^{--}$ to $\mathrm{HO}^{\bullet}$ under the basic solution (as shown in (Equation (8)) can have a significant impact. Since the reduction potential value of $\mathrm{HO}^{\bullet}$ under natural $\mathrm{pH}$ is lower than that in acidic solution (1.8 vs. 2.7V) [105], and the lifetime of $\mathrm{HO}^{\bullet}$ is shorter than $\mathrm{SO}_{4}^{\bullet-}$ (20 ns vs. $30-40 \mu \mathrm{s})$ [106]; thus, the transformation from $\mathrm{SO}_{4}^{\bullet-}(\mathrm{E}=2.6 \mathrm{~V})$ to $\mathrm{HO}^{\bullet}$ under alkaline solution might lead to a decrease of pollutant degradation. In addition, the leaching of $\mathrm{Mn}^{2+}$ from $\mathrm{Mn}$ (III) (oxyhydr)oxides in an acidic condition also should be taken into consideration for the activation of sulfate compounds (PMS/PDS). 
Table 5. The PZC values of Mn(III) (oxyhydr)oxides and pKa values of PMS/PDS and pollutants.

\begin{tabular}{ccc}
\hline Catalysts & PZC & Reference \\
$\alpha-\mathrm{Mn}_{2} \mathrm{O}_{3}$ & 4.7 & {$[88,107]$} \\
$\gamma-\mathrm{MnOOH}_{3}$ & 3.4 & {$[90]$} \\
$\mathrm{Mn}_{3} \mathrm{O}_{4}$ & $5.6-7.34$ & {$[68,87,102]$} \\
\hline Oxidants & $\mathbf{p K a}$ & Reference \\
PMS & 9.4 & {$[108]$} \\
PDS & -3.5 & {$[109]$} \\
\hline Pollutants & $\mathbf{p K a}$ & Reference \\
Phenol & 9.98 & {$[110]$} \\
Bisphenol A & $9.6-10.2$ & {$[111]$} \\
2,4-dichlorophenol & 9.4 & {$[82]$} \\
Ciprofloxacin & $8.70-10.58$ & {$[68,112]$} \\
p-Chloroaniline & 4.2 & {$[90,113]$} \\
4-Chlorophenol & 9.29 & {$[114]$} \\
Orange II & 11.4 & {$[103]$} \\
\hline
\end{tabular}

\subsection{The Effect of Inorganic Anions}

Inorganic anions are ubiquitous in various aquatic compartments. It is reported that inorganic anions can suppress the degradation of pollutants in Mn(III) (oxyhydr) oxides-activated PMS/PDS systems through competing with pollutants for radicals. Thus, to evaluate the applicability of the Mn(III) (oxyhydr)oxides + PMS/PDS system in different water matrices, the influence of inorganic anions on the removal of pollutants has been investigated by many researchers $[63,79,86,88,97]$. In this section, the effect of inorganic anions, such as carbonate / bicarbonate ions $\left(\mathrm{CO}_{3}^{2-} / \mathrm{HCO}_{3}^{-}\right)$, chloride ions $\left(\mathrm{Cl}^{-}\right)$, and nitrate $\left(\mathrm{NO}_{3}^{-}\right) /$nitrite ions $\left(\mathrm{NO}_{2}^{-}\right)$on the reactivity of $\mathrm{Mn}(\mathrm{III})$ (oxyhydr)oxides was summarized.

Carbonate $\left(\mathrm{CO}_{3}^{2-}\right) /$ bicarbonate $\left(\mathrm{HCO}_{3}^{-}\right)$can react with $\mathrm{SO}_{4}^{\cdot-}$ and $\mathrm{HO}$ ' to generate less reactive carbonate radical $\left(\mathrm{CO}_{3}^{\bullet-}\right)$ and bicarbonate radical $\left(\mathrm{HCO}_{3}^{\bullet}\right)$ (Equations (21)-(25)) leading to the inhibited degradation of pollutants [115]. However, although the redox potential of $\mathrm{CO}_{3}^{\bullet-}$ is low (1.59 V vs. NHE), it can still selectively degrade some organic pollutants with a reaction rate of $10^{3}-10^{9} \mathrm{M}^{-1} \mathrm{~s}^{-1}$ [116,117]. In addition, the presence of carbonate and bicarbonate ions can affect the stability of oxidants. For example, PDS can be activated by $\mathrm{HCO}_{3}^{-}$to generated percarbonate $\left(\mathrm{HCO}_{4}^{-}\right)$(Equation (26)) [118]. Similarly, PMS can be catalyzed by both $\mathrm{CO}_{3}^{2-}$ and $\mathrm{HCO}_{3}^{-}$to form active radicals and $\mathrm{HCO}_{4}^{-}$ (Equations (27)-(29)). Furthermore, the solution $\mathrm{pH}$ can be changed in the presence of carbonate/bicarbonate ions, which can affect the reactivity of Mn(III) (oxyhydr)oxides in PMS/PDS activation as discussed in Section 4.1.

$$
\begin{gathered}
\mathrm{SO}_{4}^{\bullet-}+\mathrm{CO}_{3}^{2-} \rightarrow \mathrm{SO}_{4}^{2-}+\mathrm{CO}_{3}^{\bullet-} \\
\mathrm{SO}_{4}^{\bullet-}+\mathrm{HCO}_{3}^{-} \rightarrow \mathrm{SO}_{4}^{2-}+\mathrm{HCO}_{3}^{\bullet} \\
\mathrm{HO}+\mathrm{CO}_{3}^{2-} \rightarrow \mathrm{OH}^{-}+\mathrm{CO}_{3}^{\bullet-} \\
\mathrm{HO}^{\bullet}+\mathrm{HCO}_{3}^{-} \rightarrow \mathrm{H}_{2} \mathrm{O}+\mathrm{HCO}_{3}^{\bullet} \\
\mathrm{HCO}_{3}^{\bullet}=\mathrm{H}^{+}+\mathrm{CO}_{3}^{\bullet-} \mathrm{pKa}=9.6 \\
\mathrm{~S}_{2} \mathrm{O}_{8}^{2-}+\mathrm{HCO}_{3}^{-}+2 \mathrm{OH}^{-} \rightarrow \mathrm{HCO}_{4}^{-}+2 \mathrm{SO}_{4}^{2-}+\mathrm{H}_{2} \mathrm{O} \\
\mathrm{HSO}_{5}^{-}+\mathrm{CO}_{3}^{2-}+\mathrm{H}^{+} \rightarrow \mathrm{SO}_{4}^{\bullet-}+2 \mathrm{OH}^{-}+\mathrm{CO}_{2} \\
\mathrm{HSO}_{5}^{-}+\mathrm{HCO}_{3}^{-} \rightarrow \mathrm{SO}_{4}^{\bullet-}+2 \mathrm{OH}^{-}+\mathrm{CO}_{2} \\
\mathrm{HSO}_{5}^{-}+\mathrm{HCO}_{3}^{-} \rightarrow \mathrm{SO}_{4}^{2-}+\mathrm{HCO}_{4}^{-}+\mathrm{H}^{+}
\end{gathered}
$$

Chloride ion $\left(\mathrm{Cl}^{-}\right)$exists widely in various water bodies including surface water, groundwater, and industrial wastewater [119]. The influence of $\mathrm{Cl}^{-}$on the degradation 
of organic pollutants by sulfate radical-based AOPs (SR-AOP) was reported by previous studies [120-123]. Generally, $\mathrm{Cl}^{-}$can react with $\mathrm{SO}_{4}^{\bullet-}$ to generate $\mathrm{Cl}^{\bullet}$, which can react with another $\mathrm{Cl}^{-}$to form $\mathrm{Cl}_{2}^{\bullet-}$ (Equations (30)-(31)) [122]. Both $\mathrm{Cl}^{\bullet}$ and $\mathrm{Cl}_{2}^{\bullet-}$ have low reduction potentials $\left(\mathrm{E}_{0}=2.4\right.$ and $\left.2.0 \mathrm{~V}\right)$ in comparison with $\mathrm{SO}_{4}^{\cdot-}$, thus the consumption of $\mathrm{SO}_{4}^{--}$by $\mathrm{Cl}^{-}$leads to the decrease of organic pollutant degradation $[124,125]$. However, $\mathrm{Cl}^{\bullet}$ was believed to own higher selectivity on electron-rich compounds than nonselective $\mathrm{SO}_{4}^{\bullet-}$, which can offset the negative effect of $\mathrm{Cl}^{-}$on $\mathrm{SO}_{4}^{--}$[126]. Therefore, the conflicting effect of $\mathrm{Cl}^{-}$on organic pollutants in SR-AOP might be attributed to the different reactivity of pollutants with $\mathrm{Cl}^{\bullet}$ and $\mathrm{Cl}_{2}^{\bullet-}$. In addition, the reactivity of $\mathrm{HO}^{\bullet}$ can also be suppressed by $\mathrm{Cl}^{-}$due to the formation of low active radical $\mathrm{ClOH}^{\bullet-}$ (Equation (32)) [127].

$$
\begin{gathered}
\mathrm{SO}_{4}^{\bullet-}+\mathrm{Cl}^{-} \rightarrow \mathrm{SO}_{4}^{2-}+\mathrm{Cl}^{\bullet} \\
\mathrm{Cl}^{\bullet}+\mathrm{Cl}^{-} \rightarrow \mathrm{Cl}_{2}^{\bullet-} \\
\mathrm{HO}^{\bullet}+\mathrm{Cl}^{-} \rightarrow \mathrm{ClOH}^{\bullet-}
\end{gathered}
$$

Nitrate $\left(\mathrm{NO}_{3}^{-}\right)$and nitrite $\left(\mathrm{NO}_{2}^{-}\right)$can be commonly found in various water matrices [119]. Both $\mathrm{NO}_{3}^{-}$and $\mathrm{NO}_{2}^{-}$are able to react with $\mathrm{SO}_{4}^{\bullet--}$ to generate low reactive $\mathrm{NO}_{3}^{\bullet}$ $\left(\mathrm{E}_{0}=2.3-2.5 \mathrm{~V}\right)$ and $\mathrm{NO}_{2}^{\bullet}$ radicals $\left(\mathrm{E}_{0}=1.03 \mathrm{~V}\right)$ (Equations (33)-(34)) [25]. The reaction rate of $\mathrm{SO}_{4}^{--}$with $\mathrm{NO}_{3}^{-}$and $\mathrm{NO}_{2}^{-}$are $5 \times 10^{4} \mathrm{M}^{-1} \mathrm{~s}^{-1}$ and $8.8 \times 10^{8} \mathrm{M}^{-1} \mathrm{~s}^{-1}$, separately [45]. Thus, $\mathrm{NO}_{2}^{-}$, compared with $\mathrm{NO}_{3}^{-}$, has higher reactivity in $\mathrm{SO}_{4}^{\bullet-}$ consumption. In addition and in a similar way, $\mathrm{NO}_{2}^{-}$was also reported as the sink of $\mathrm{HO}^{\bullet}$ radicals (Equation (35)) [128].

$$
\begin{aligned}
& \mathrm{SO}_{4}^{\bullet-}+\mathrm{NO}_{3}^{-} \rightarrow \mathrm{SO}_{4}^{2-}+\mathrm{NO}_{3}^{\bullet} \\
& \mathrm{SO}_{4}^{\bullet-}+\mathrm{NO}_{2}^{-} \rightarrow \mathrm{SO}_{4}^{2-}+\mathrm{NO}_{2}^{\bullet} \\
& \mathrm{HO}^{\bullet}+\mathrm{NO}_{2}^{-} \rightarrow \mathrm{OH}^{-}+\mathrm{NO}_{2}^{\bullet}
\end{aligned}
$$

\section{Summary and Outlooks}

This review summarized the activation of PMS and PDS by manganese(III) (oxyhydr)oxides for the degradation of recalcitrant pollutants. The desirable morphologies and facets (e.g., cubic structure with (001) facet exposure) can effectively enhance the reactivity of $\mathrm{Mn}$ (III) (oxyhydr)oxides in the activation of PDS and PMS. Mn(III) (oxyhydr)oxides showed different reactivity in radical precursors activation. Specifically, both radical (for example, sulfate and hydroxyl radical) and non-radical (such as singlet oxygen) were generated in the Mn(III) (oxyhydr)oxide-activated PMS system. The activation of PDS by $\alpha-\mathrm{Mn}_{2} \mathrm{O}_{3}$ and $\gamma-\mathrm{MnOOH}$ were mainly through the formation of singlet oxygen and the catalyst surface activated complex. The activity of Mn(III) (oxyhydr)oxides in PDS and PMS activation can be influenced by the solution $\mathrm{pH}$ due to the occurrence of the electrostatic effect. Moreover, the inhibition effect of inorganic anions (such as carbonate/bicarbonate ions, chloride ions, and nitrate/nitrite ions) on the catalytic performance of $\mathrm{Mn}$ (III) (oxyhydr)oxides were discussed in detail.

Given this comprehensive summary, some future outlooks are proposed.

Although previous studies already identified the generation of ${ }^{1} \mathrm{O}_{2}$ in $\alpha-\mathrm{Mn}_{2} \mathrm{O}_{3} / \mathrm{PDS}$ system using the ESR and quenching experiments, the detailed catalytic process of PDS on the surface of $\mathrm{Mn}_{2} \mathrm{O}_{3}$ remains elusive. Further studies are needed for a better understanding of the activation mechanism of PDS by $\alpha-\mathrm{Mn}_{2} \mathrm{O}_{3}$. Second, detailed studies are required to exploit the potential application of $\alpha-\mathrm{Mn}_{2} \mathrm{O}_{3}$ or $\gamma-\mathrm{MnOOH}$-based composites in PDS activation to understand the synergistic performance of $\alpha-\mathrm{Mn}_{2} \mathrm{O}_{3}$ or $\gamma-\mathrm{MnOOH}$ with other loaded materials (such as active carbon, graphene, and transition metals). This will open up new research avenues in the field of water remediation technologies, with the aim to improve the reactivity of $\alpha-\mathrm{Mn}_{2} \mathrm{O}_{3} / \gamma-\mathrm{MnOOH}$ in PDS activation.

The high-scale or industrial application of SR-AOP seems difficult to implement, and that merits being resolved. The development of new modeling approaches that account for the upscaling of different involved reactions and the complexity of heterogeneous reactions 
at Mn-oxides/water interfaces becomes urgent. More experimental work is also needed to develop new Mn-bearing oxides supported with high catalytic efficiency, suitable for industrial applications, and yet are relevant from both economic and environmental points of view.

Author Contributions: Draft preparation, D.J.; conceptualization, D.J., M.B.; revised the paper D.J., G.M., M.B., K.H. All authors have read and agreed to the published version of the manuscript.

Funding: No funding.

Institutional Review Board Statement: Not applicable.

Informed Consent Statement: Not applicable.

Data Availability Statement: Not applicable.

Acknowledgments: We gratefully acknowledge the Chinese Scholarship Council of China for providing financial support for Daqing Jia. We acknowledge the program PAI (Pack Ambition Recherche) SOLDE from the Region Auvergne Rhône Alpes for the financial support of D.J. in this project.

Conflicts of Interest: The authors declare no conflict of interest.

\section{References}

1. Rathi, B.S.; Kumar, P.S.; Show, P.-L. A Review on Effective Removal of Emerging Contaminants from Aquatic Systems: Current Trends and Scope for Further Research. J. Hazard. Mater. 2021, 409, 124413. [CrossRef]

2. Kasonga, T.K.; Coetzee, M.A.A.; Kamika, I.; Ngole-Jeme, V.M.; Benteke Momba, M.N. Endocrine-Disruptive Chemicals as Contaminants of Emerging Concern in Wastewater and Surface Water: A Review. J. Environ. Manag. 2021, 277, 111485. [CrossRef] [PubMed]

3. Chen, L.; Fu, W.; Tan, Y.; Zhang, X. Emerging Organic Contaminants and Odorous Compounds in Secondary Effluent Wastewater: Identification and Advanced Treatment. J. Hazard. Mater. 2021, 408, 124817. [CrossRef] [PubMed]

4. Sui, Q.; Jiang, C.; Zhang, J.; Yu, D.; Chen, M.; Wang, Y.; Wei, Y. Does the Biological Treatment or Membrane Separation Reduce the Antibiotic Resistance Genes from Swine Wastewater through a Sequencing-Batch Membrane Bioreactor Treatment Process. Environ. Int. 2018, 118, 274-281. [CrossRef]

5. Verma, S.; Daverey, A.; Sharma, A. Slow Sand Filtration for Water and Wastewater Treatment-A Review. Environ. Technol. Rev. 2017, 6, 47-58. [CrossRef]

6. Rebosura, M.; Salehin, S.; Pikaar, I.; Keller, J.; Sharma, K.; Yuan, Z. The Impact of Primary Sedimentation on the Use of Iron-Rich Drinking Water Sludge on the Urban Wastewater System. J. Hazard. Mater. 2021, 402, 124051. [CrossRef] [PubMed]

7. Huang, H.; Chen, Y.; Jiang, Y.; Ding, L. Treatment of Swine Wastewater Combined with MgO-Saponification Wastewater by Struvite Precipitation Technology. Chem. Eng. J. 2014, 254, 418-425. [CrossRef]

8. Lv, M.; Zhang, Z.; Zeng, J.; Liu, J.; Sun, M.; Yadav, R.S.; Feng, Y. Roles of Magnetic Particles in Magnetic Seeding CoagulationFlocculation Process for Surface Water Treatment. Sep. Purif. Technol. 2019, 212, 337-343. [CrossRef]

9. Teh, C.Y.; Budiman, P.M.; Shak, K.P.Y.; Wu, T.Y. Recent Advancement of Coagulation-Flocculation and Its Application in Wastewater Treatment. Ind. Eng. Chem. Res. 2016, 55, 4363-4389. [CrossRef]

10. Wei, H.; Gao, B.; Ren, J.; Li, A.; Yang, H. Coagulation/Flocculation in Dewatering of Sludge: A Review. Water Res. 2018, 143, 608-631. [CrossRef]

11. Béguin, P.; Aubert, J.-P. The Biological Degradation of Cellulose. FEMS Microbiol. Rev. 1994, 13, 25-58. [CrossRef]

12. Durai, G.; Rajasimman, M. Biological Treatment of Tannery Wastewater-A Review. J. Environ. Sci. Technol. 2010, 4, 1-17. [CrossRef]

13. Li, Y.; Dong, H.; Li, L.; Tang, L.; Tian, R.; Li, R.; Chen, J.; Xie, Q.; Jin, Z.; Xiao, J.; et al. Recent Advances in Waste Water Treatment through Transition Metal Sulfides-Based Advanced Oxidation Processes. Water Res. 2021, 192, 116850. [CrossRef] [PubMed]

14. Hu, X.; Wang, X.; Ban, Y.; Ren, B. A Comparative Study of UV-Fenton, UV- $\mathrm{H}_{2} \mathrm{O}_{2}$ and Fenton Reaction Treatment of Landfill Leachate. Environ. Technol. 2011, 32, 945-951. [CrossRef] [PubMed]

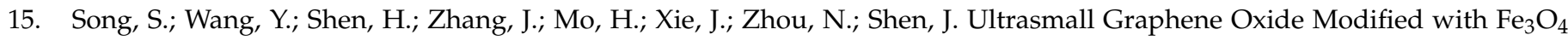
Nanoparticles as a Fenton-Like Agent for Methylene Blue Degradation. ACS Appl. Nano Mater. 2019, 2, 7074-7084. [CrossRef]

16. Lan, H.; Wang, F.; Lan, M.; An, X.; Liu, H.; Qu, J. Hydrogen-Bond-Mediated Self-Assembly of Carbon-Nitride-Based PhotoFenton-like Membranes for Wastewater Treatment. Environ. Sci. Technol. 2019, 53, 6981-6988. [CrossRef]

17. Vermilyea, A.W.; Voelker, B.M. Photo-Fenton Reaction at Near Neutral PH. Environ. Sci. Technol. 2009, 43, 6927-6933. [CrossRef]

18. Ding, J.; Sun, Y.-G.; Ma, Y.-L. Highly Stable Mn-Doped Metal-Organic Framework Fenton-Like Catalyst for the Removal of Wastewater Organic Pollutants at All Light Levels. ACS Omega 2021, 6, 2949-2955. [CrossRef]

19. Jaafarzadeh, N.; Takdastan, A.; Jorfi, S.; Ghanbari, F.; Ahmadi, M.; Barzegar, G. The Performance Study on Ultrasonic/ $\mathrm{Fe}_{3} \mathrm{O}_{4} / \mathrm{H}_{2} \mathrm{O}_{2}$ for Degradation of Azo Dye and Real Textile Wastewater Treatment. J. Mol. Liq. 2018, 256, 462-470. [CrossRef] 
20. Mahamuni, N.N.; Adewuyi, Y.G. Advanced Oxidation Processes (AOPs) Involving Ultrasound for Waste Water Treatment: A Review with Emphasis on Cost Estimation. Ultrason. Sonochem. 2010, 17, 990-1003. [CrossRef] [PubMed]

21. Nidheesh, P.V.; Gandhimathi, R. Trends in Electro-Fenton Process for Water and Wastewater Treatment: An Overview. Desalination 2012, 299, 1-15. [CrossRef]

22. Melin, V.; Salgado, P.; Thiam, A.; Henríquez, A.; Mansilla, H.D.; Yáñez, J.; Salazar, C. Study of Degradation of Amitriptyline Antidepressant by Different Electrochemical Advanced Oxidation Processes. Chemosphere 2021, 274, 129683. [CrossRef]

23. Sgroi, M.; Anumol, T.; Vagliasindi, F.G.A.; Snyder, S.A.; Roccaro, P. Comparison of the $\mathrm{New}_{2} \mathrm{Cl}_{2} / \mathrm{O}_{3} / \mathrm{UV}$ Process with Different Ozone- and UV-Based AOPs for Wastewater Treatment at Pilot Scale: Removal of Pharmaceuticals and Changes in Fluorescing Organic Matter. Sci. Total Environ. 2021, 765, 142720. [CrossRef] [PubMed]

24. Chen, H.; Wang, J. Degradation and Mineralization of Ofloxacin by Ozonation and Peroxone $\left(\mathrm{O}_{3} / \mathrm{H}_{2} \mathrm{O}_{2}\right)$ Process. Chemosphere 2021, 269, 128775. [CrossRef] [PubMed]

25. Giannakis, S.; Lin, K.-Y.A.; Ghanbari, F. A Review of the Recent Advances on the Treatment of Industrial Wastewaters by Sulfate Radical-Based Advanced Oxidation Processes (SR-AOPs). Chem. Eng. J. 2021, 406, 127083. [CrossRef]

26. Duan, X.; Yang, S.; Wacławek, S.; Fang, G.; Xiao, R.; Dionysiou, D.D. Limitations and Prospects of Sulfate-Radical Based Advanced Oxidation Processes. J. Environ. Chem. Eng. 2020, 8, 103849. [CrossRef]

27. Solís, R.R.; Rivas, F.J.; Chávez, A.M.; Dionysiou, D.D. Peroxymonosulfate/Solar Radiation Process for the Removal of Aqueous Microcontaminants. Kinetic Modeling, Influence of Variables and Matrix Constituents. J. Hazard. Mater. 2020, $400,123118$. [CrossRef] [PubMed]

28. Chen, C.; Feng, H.; Deng, Y. Re-Evaluation of Sulfate Radical Based-Advanced Oxidation Processes (SR-AOPs) for Treatment of Raw Municipal Landfill Leachate. Water Res. 2019, 153, 100-107. [CrossRef] [PubMed]

29. Anipsitakis, G.P.; Dionysiou, D.D. Transition Metal/UV-Based Advanced Oxidation Technologies for Water Decontamination. Appl. Catal. B Environ. 2004, 54, 155-163. [CrossRef]

30. Ao, X.; Liu, W. Degradation of Sulfamethoxazole by Medium Pressure UV and Oxidants: Peroxymonosulfate, Persulfate, and Hydrogen Peroxide. Chem. Eng. J. 2017, 313, 629-637. [CrossRef]

31. Lin, H.; Li, S.; Deng, B.; Tan, W.; Li, R.; Xu, Y.; Zhang, H. Degradation of Bisphenol A by Activating Peroxymonosulfate with $\mathrm{Mn}_{0.6} \mathrm{Zn}_{0.4} \mathrm{Fe}_{2} \mathrm{O}_{4}$ Fabricated from Spent Zn-Mn Alkaline Batteries. Chem. Eng. J. 2019, 364, 541-551. [CrossRef]

32. Anipsitakis, G.P.; Dionysiou, D.D. Radical Generation by the Interaction of Transition Metals with Common Oxidants. Environ. Sci. Technol. 2004, 38, 3705-3712. [CrossRef]

33. Huang, W.; Bianco, A.; Brigante, M.; Mailhot, G. UVA-UVB Activation of Hydrogen Peroxide and Persulfate for Advanced Oxidation Processes: Efficiency, Mechanism and Effect of Various Water Constituents. J. Hazard. Mater. 2018, 347, $279-287$. [CrossRef] [PubMed]

34. Gabet, A.; Métivier, H.; de Brauer, C.; Mailhot, G.; Brigante, M. Hydrogen Peroxide and Persulfate Activation Using UVA-UVB Radiation: Degradation of Estrogenic Compounds and Application in Sewage Treatment Plant Waters. J. Hazard. Mater. 2021, 405, 124693. [CrossRef] [PubMed]

35. Ahn, Y.-Y.; Choi, J.; Kim, M.; Kim, M.S.; Lee, D.; Bang, W.H.; Yun, E.-T.; Lee, H.; Lee, J.-H.; Lee, C.; et al. Chloride-Mediated Enhancement in Heat-Induced Activation of Peroxymonosulfate: New Reaction Pathways for Oxidizing Radical Production. Environ. Sci. Technol. 2021, 55, 5382-5392. [CrossRef]

36. Hu, J.; Zeng, X.; Yin, Y.; Liu, Y.; Li, Y.; Hu, X.; Zhang, L.; Zhang, X. Accelerated Alkaline Activation of Peroxydisulfate by Reduced Rubidium Tungstate Nanorods for Enhanced Degradation of Bisphenol A. Environ. Sci. Nano 2020, 7, 3547-3556. [CrossRef]

37. Rodríguez-Chueca, J.; Giannakis, S.; Marjanovic, M.; Kohantorabi, M.; Gholami, M.R.; Grandjean, D.; de Alencastro, L.F.; Pulgarín,

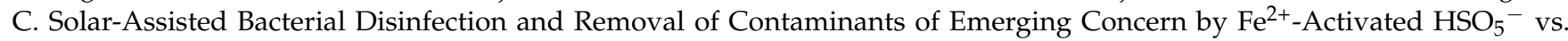
$\mathrm{S}_{2} \mathrm{O}_{8}{ }^{2-}$ in Drinking Water. Appl. Catal. B Environ. 2019, 248, 62-72. [CrossRef]

38. Oh, W.-D.; Lim, T.-T. Design and Application of Heterogeneous Catalysts as Peroxydisulfate Activator for Organics Removal: An Overview. Chem. Eng. J. 2019, 358, 110-133. [CrossRef]

39. Jia, D.; Li, Q.; Hanna, K.; Mailhot, G.; Brigante, M. Efficient Removal of Estrogenic Compounds in Water by Mn ${ }^{\mathrm{III}}$-Activated Peroxymonosulfate: Mechanisms and Application in Sewage Treatment Plant Water. Environ. Pollut. 2021, 288, 117728. [CrossRef]

40. Taujale, S.; Baratta, L.R.; Huang, J.; Zhang, H. Interactions in Ternary Mixtures of $\mathrm{MnO}_{2}, \mathrm{Al}_{2} \mathrm{O}_{3}$, and Natural Organic Matter (NOM) and the Impact on $\mathrm{MnO}_{2}$ Oxidative Reactivity. Environ. Sci. Technol. 2016, 50, 2345-2353. [CrossRef]

41. Zhu, S.; Li, X.; Kang, J.; Duan, X.; Wang, S. Persulfate Activation on Crystallographic Manganese Oxides: Mechanism of Singlet Oxygen Evolution for Nonradical Selective Degradation of Aqueous Contaminants. Environ. Sci. Technol. 2019, 53, 307-315. [CrossRef] [PubMed]

42. Zhou, Z.-G.; Du, H.-M.; Dai, Z.; Mu, Y.; Tong, L.-L.; Xing, Q.-J.; Liu, S.-S.; Ao, Z.; Zou, J.-P. Degradation of Organic Pollutants by Peroxymonosulfate Activated by $\mathrm{MnO}_{2}$ with Different Crystalline Structures: Catalytic Performances and Mechanisms. Chem. Eng. J. 2019, 374, 170-180. [CrossRef]

43. Huang, J.; Dai, Y.; Singewald, K.; Liu, C.-C.; Saxena, S.; Zhang, H. Effects of $\mathrm{MnO}_{2}$ of Different Structures on Activation of Peroxymonosulfate for Bisphenol A Degradation under Acidic Conditions. Chem. Eng. J. 2019, 370, 906-915. [CrossRef]

44. Saputra, E.; Muhammad, S.; Sun, H.; Ang, H.-M.; Tadé, M.O.; Wang, S. Manganese Oxides at Different Oxidation States for Heterogeneous Activation of Peroxymonosulfate for Phenol Degradation in Aqueous Solutions. Appl. Catal. B Environ. 2013, 142-143, 729-735. [CrossRef] 
45. Huang, J.; Zhang, H. Mn-Based Catalysts for Sulfate Radical-Based Advanced Oxidation Processes: A Review. Environ. Int. 2019, 133, 105141. [CrossRef]

46. Liu, W.; Sutton, N.B.; Rijnaarts, H.H.M.; Langenhoff, A.A.M. Pharmaceutical Removal from Water with Iron- or Manganese-Based Technologies: A Review. Crit. Rev. Environ. Sci. Technol. 2016, 46, 1584-1621. [CrossRef]

47. Remucal, C.K.; Ginder-Vogel, M. A Critical Review of the Reactivity of Manganese Oxides with Organic Contaminants. Environ. Sci. Proc. Impacts 2014, 16, 1247. [CrossRef] [PubMed]

48. Wu, P.; Jin, X.; Qiu, Y.; Ye, D. Recent Progress of Thermocatalytic and Photo/Thermocatalytic Oxidation for VOCs Purification over Manganese-Based Oxide Catalysts. Environ. Sci. Technol. 2021, 55, 4268-4286. [CrossRef]

49. Huang, J.; Zhong, S.; Dai, Y.; Liu, C.-C.; Zhang, H. Effect of $\mathrm{MnO}_{2}$ Phase Structure on the Oxidative Reactivity toward Bisphenol A Degradation. Environ. Sci. Technol. 2018, 52, 11309-11318. [CrossRef]

50. Post, J.E. Manganese Oxide Minerals: Crystal Structures and Economic and Environmental Significance. Proc. Natl. Acad. Sci. USA 1999, 96, 3447-3454. [CrossRef]

51. Ghosh, S.K. Diversity in the Family of Manganese Oxides at the Nanoscale: From Fundamentals to Applications. ACS Omega 2020, 5, 25493-25504. [CrossRef] [PubMed]

52. Geller, S. Structure of $\alpha-\mathrm{Mn}_{2} \mathrm{O}_{3},\left(\mathrm{Mn}_{0.983} \mathrm{Fe}_{0.017}\right)_{2} \mathrm{O}_{3}$ and $\left(\mathrm{Mn}_{0.37} \mathrm{Fe}_{0.63}\right)_{2} \mathrm{O}_{3}$ and Relation to Magnetic Ordering. Acta Crystallogr. B. Struct. Sci. Cryst. Eng. Mater. 1971, 27, 821-828. [CrossRef]

53. Baron, V.; Gutzmer, J.; Rundlof, H.; Tellgren, R. The Influence of Iron Substitution in the Magnetic Properties of Hausmannite, $\mathrm{Mn}^{2+}(\mathrm{Fe}, \mathrm{Mn})_{2}^{3+} \mathrm{O}_{4}$. Am. Mineral. 1998, 83, 786-793. [CrossRef]

54. Buerger, M.J. The Symmetry and Crystal Structure of Manganite, Mn (OH)O. Z. Kristallogr. Cryst. Mater. 1936, 95, 163-174. [CrossRef]

55. Saputra, E.; Muhammad, S.; Sun, H.; Ang, H.-M.; Tadé, M.O.; Wang, S. Shape-Controlled Activation of Peroxymonosulfate by Single Crystal $\alpha-\mathrm{Mn}_{2} \mathrm{O}_{3}$ for Catalytic Phenol Degradation in Aqueous Solution. Appl. Catal. B Environ. 2014, 154-155, $246-251$. [CrossRef]

56. Cheng, L.; Men, Y.; Wang, J.; Wang, H.; An, W.; Wang, Y.; Duan, Z.; Liu, J. Crystal Facet-Dependent Reactivity of $\alpha-\mathrm{Mn}_{2} \mathrm{O}_{3}$ Microcrystalline Catalyst for Soot Combustion. Appl. Catal. B Environ. 2017, 204, 374-384. [CrossRef]

57. Ji, F.; Men, Y.; Wang, J.; Sun, Y.; Wang, Z.; Zhao, B.; Tao, X.; Xu, G. Promoting Diesel Soot Combustion Efficiency by Tailoring the Shapes and Crystal Facets of Nanoscale $\mathrm{Mn}_{3} \mathrm{O}_{4}$. Appl. Catal. B Environ. 2019, 242, 227-237. [CrossRef]

58. Liu, J.; Jiang, L.; Zhang, T.; Jin, J.; Yuan, L.; Sun, G. Activating $\mathrm{Mn}_{3} \mathrm{O}_{4}$ by Morphology Tailoring for Oxygen Reduction Reaction. Electrochim. Acta 2016, 205, 38-44. [CrossRef]

59. He, D.; Li, Y.; Lyu, C.; Song, L.; Feng, W.; Zhang, S. New Insights into MnOOH/Peroxymonosulfate System for Catalytic Oxidation of 2,4-Dichlorophenol: Morphology Dependence and Mechanisms. Chemosphere 2020, 255, 126961. [CrossRef] [PubMed]

60. Yan, H.; Shen, Q.; Sun, Y.; Zhao, S.; Lu, R.; Gong, M.; Liu, Y.; Zhou, X.; Jin, X.; Feng, X.; et al. Tailoring Facets of $\alpha-\mathrm{Mn}_{2} \mathrm{O}_{3}$ Microcrystalline Catalysts for Enhanced Selective Oxidation of Glycerol to Glycolic Acid. ACS Catal. 2021, 11, $6371-6383$. [CrossRef]

61. Fan, Z.; Wang, Z.; Shi, J.-W.; Gao, C.; Gao, G.; Wang, B.; Wang, Y.; Chen, X.; He, C.; Niu, C. Charge-Redistribution-Induced New Active Sites on $\left(\begin{array}{l}0 \\ 0\end{array}\right.$ 1) Facets of $\alpha-\mathrm{Mn}_{2} \mathrm{O}_{3}$ for Significantly Enhanced Selective Catalytic Reduction of NOx by NH3. J. Catal. 2019, 370, 30-37. [CrossRef]

62. Wang, F.; Xiao, M.; Ma, X.; Wu, S.; Ge, M.; Yu, X. Insights into the Transformations of Mn Species for Peroxymonosulfate Activation by Tuning the $\mathrm{Mn}_{3} \mathrm{O}_{4}$ Shapes. Chem. Eng. J. 2021, 404, 127097. [CrossRef]

63. Zhang, H.; Wang, X.; Li, Y.; Zuo, K.; Lyu, C. A Novel MnOOH Coated Nylon Membrane for Efficient Removal of 2,4Dichlorophenol through Peroxymonosulfate Activation. J. Hazard. Mater. 2021, 414, 125526. [CrossRef] [PubMed]

64. Shokoohi, R.; Khazaei, M.; Godini, K.; Azarian, G.; Latifi, Z.; Javadimanesh, L.; Zolghadr Nasab, H. Degradation and Mineralization of Methylene Blue Dye by Peroxymonosulfate/ $\mathrm{Mn}_{3} \mathrm{O}_{4}$ Nanoparticles Using Central Composite Design: Kinetic Study. Inorg. Chem. Commun. 2021, 127, 108501. [CrossRef]

65. Li, Y.; Li, D.; Fan, S.; Yang, T.; Zhou, Q. Facile Template Synthesis of Dumbbell-like $\mathrm{Mn}_{2} \mathrm{O}_{3}$ with Oxygen Vacancies for Efficient Degradation of Organic Pollutants by Activating Peroxymonosulfate. Catal. Sci. Technol. 2020, 10, 864-875. [CrossRef]

66. Wang, Q.; Li, Y.; Shen, Z.; Liu, X.; Jiang, C. Facile Synthesis of Three-Dimensional $\mathrm{Mn}_{3} \mathrm{O}_{4}$ Hierarchical Microstructures for Efficient Catalytic Phenol Oxidation with Peroxymonosulfate. Appl. Surf. Sci. 2019, 495, 143568. [CrossRef]

67. Zhang, L.; Tong, T.; Wang, N.; Ma, W.; Sun, B.; Chu, J.; Lin, K.A.; Du, Y. Facile Synthesis of Yolk-Shell Mn ${ }_{3} \mathrm{O}_{4} \mathrm{Microspheres} \mathrm{as}$ a High-Performance Peroxymonosulfate Activator for Bisphenol A Degradation. Ind. Eng. Chem. Res. 2019, 58, $21304-21311$. [CrossRef]

68. Zhao, Z.; Zhao, J.; Yang, C. Efficient Removal of Ciprofloxacin by Peroxymonosulfate $/ \mathrm{Mn}_{3} \mathrm{O}_{4}-\mathrm{MnO}_{2}$ Catalytic Oxidation System. Chem. Eng. J. 2017, 327, 481-489. [CrossRef]

69. Hu, L.; Deng, G.; Lu, W.; Lu, Y.; Zhang, Y. Peroxymonosulfate Activation by $\mathrm{Mn}_{3} \mathrm{O}_{4} /$ Metal-Organic Framework for Degradation of Refractory Aqueous Organic Pollutant Rhodamine B. Chinese J. Catal. 2017, 38, 1360-1372. [CrossRef]

70. Shokoohi, R.; Foroughi, M.; Latifi, Z.; Goljani, H.; Ansari, A.; Samarghandi, M.R.; Nematollahi, D. Comparing the Performance of the Peroxymonosulfate $/ \mathrm{Mn}_{3} \mathrm{O}_{4}$ and Three-Dimensional Electrochemical Processes for Methylene Blue Removal from Aqueous Solutions: Kinetic Studies. Colloid Interface Sci. Commun. 2021, 42, 100394. [CrossRef] 
71. Oh, W.-D.; Dong, Z.; Lim, T.-T. Generation of Sulfate Radical through Heterogeneous Catalysis for Organic Contaminants Removal: Current Development, Challenges and Prospects. Appl. Catal. B Environ. 2016, 194, 169-201. [CrossRef]

72. Yermakov, A.N.; Zhitomirsky, B.M.; Poskrebyshev, G.A.; Sozurakov, D.M. The Branching Ratio of Peroxomonosulfate Radicals $\left(\mathrm{SO}_{5}{ }^{-}\right)$Self-Reaction Aqueous Solution. J. Phys. Chem. 1993, 97, 10712-10714. [CrossRef]

73. Ghanbari, F.; Moradi, M. Application of Peroxymonosulfate and Its Activation Methods for Degradation of Environmental Organic Pollutants: Review. Chem. Eng. J. 2017, 310, 41-62. [CrossRef]

74. Evans, D.F.; Upton, M.W. Studies on Singlet Oxygen in Aqueous Solution. Part 3. The Decomposition of Peroxy-Acids. J. Chem. Soc. Dalton Trans. 1985, 6, 1151-1153. [CrossRef]

75. Ball, D.L.; Edwards, J.O. The Kinetics and Mechanism of the Decomposition of Caro's Acid. I. J. Am. Chem. Soc. 1956, 78, 1125-1129. [CrossRef]

76. Chen, C.; Xie, M.; Kong, L.; Lu, W.; Feng, Z.; Zhan, J. $\mathrm{Mn}_{3} \mathrm{O}_{4}$ Nanodots Loaded G-C3N4 Nanosheets for Catalytic Membrane Degradation of Organic Contaminants. J. Hazard. Mater. 2020, 390, 122146. [CrossRef]

77. Chen, G.; Nengzi, L.-C.; Gao, Y.; Zhu, G.; Gou, J.; Cheng, X. Degradation of Tartrazine by Peroxymonosulfate through Magnetic $\mathrm{Fe}_{2} \mathrm{O}_{3} / \mathrm{Mn}_{2} \mathrm{O}_{3}$ Composites Activation. Chin. Chem. Lett. 2020, 31, 2730-2736. [CrossRef]

78. Saputra, E.; Muhammad, S.; Sun, H.; Ang, H.-M.; Tadé, M.O.; Wang, S. A Comparative Study of Spinel Structured $\mathrm{Mn}_{3} \mathrm{O}_{4}, \mathrm{Co}_{3} \mathrm{O}_{4}$ and $\mathrm{Fe}_{3} \mathrm{O}_{4}$ Nanoparticles in Catalytic Oxidation of Phenolic Contaminants in Aqueous Solutions. J. Colloid Interface Sci. 2013, 407, 467-473. [CrossRef]

79. Li, N.; Li, R.; Yu, Y.; Zhao, J.; Yan, B.; Chen, G. Efficient Degradation of Bentazone via Peroxymonosulfate Activation by 1D/2D $\gamma$-MnOOH-RGO under Simulated Sunlight: Performance and Mechanism Insight. Sci. Total Environ. 2020, 741, 140492. [CrossRef] [PubMed]

80. Tian, N.; Tian, X.; Nie, Y.; Yang, C.; Zhou, Z.; Li, Y. Enhanced 2, 4-Dichlorophenol Degradation at PH 3-11 by Peroxymonosulfate via Controlling the Reactive Oxygen Species over Ce Substituted 3D Mn $\mathrm{O}_{3}$. Chem. Eng. J. 2019, 355, 448-456. [CrossRef]

81. Yao, Y.; Xu, C.; Yu, S.; Zhang, D.; Wang, S. Facile Synthesis of $\mathrm{Mn}_{3} \mathrm{O}_{4}$-Reduced Graphene Oxide Hybrids for Catalytic Decomposition of Aqueous Organics. Ind. Eng. Chem. Res. 2013, 52, 3637-3645. [CrossRef]

82. Khan, A.; Zou, S.; Wang, T.; Ifthikar, J.; Jawad, A.; Liao, Z.; Shahzad, A.; Ngambia, A.; Chen, Z. Facile Synthesis of Yolk Shell $\mathrm{Mn}_{2} \mathrm{O}_{3} @ \mathrm{Mn}_{5} \mathrm{O}_{8}$ as an Effective Catalyst for Peroxymonosulfate Activation. Phys. Chem. Chem. Phys. 2018, 20, 13909-13919. [CrossRef] [PubMed]

83. Yang, B.; Tian, Z.; Wang, B.; Sun, Z.; Zhang, L.; Guo, Y.; Li, H.; Yan, S. Facile Synthesis of $\mathrm{Fe}_{3} \mathrm{O}_{4} / \mathrm{Hierarchical-Mn}_{3} \mathrm{O}_{4} / \mathrm{Graphene}$ Oxide as a Synergistic Catalyst for Activation of Peroxymonosulfate for Degradation of Organic Pollutants. RSC Adv. 2015, 5 20674-20683. [CrossRef]

84. Saputra, E.; Zhang, H.; Liu, Q.; Sun, H.; Wang, S. Egg-Shaped Core/Shell $\alpha-\mathrm{Mn}_{2} \mathrm{O}_{3} @ \alpha-\mathrm{MnO}_{2}$ as Heterogeneous Catalysts for Decomposition of Phenolics in Aqueous Solutions. Chemosphere 2016, 159, 351-358. [CrossRef]

85. Khan, A.; Wang, H.; Liu, Y.; Jawad, A.; Ifthikar, J.; Liao, Z.; Wang, T.; Chen, Z. Highly Efficient $\alpha-\mathrm{Mn}_{2} \mathrm{O}_{3} @ \alpha-\mathrm{MnO}_{2}-500$ Nanocomposite for Peroxymonosulfate Activation: Comprehensive Investigation of Manganese Oxides. J. Mater. Chem. A 2018, 6, 1590-1600. [CrossRef]

86. Huang, Y.; Nengzi, L.; Zhang, X.; Gou, J.; Gao, Y.; Zhu, G.; Cheng, Q.; Cheng, X. Catalytic Degradation of Ciprofloxacin by Magnetic $\mathrm{CuS} / \mathrm{Fe}_{2} \mathrm{O}_{3} / \mathrm{Mn}_{2} \mathrm{O}_{3}$ Nanocomposite Activated Peroxymonosulfate: Influence Factors, Degradation Pathways and Reaction Mechanism. Chem. Eng. J. 2020, 388, 124274. [CrossRef]

87. Shabanloo, A.; Salari, M.; Shabanloo, N.; Dehghani, M.H.; Pittman, C.U.; Mohan, D. Heterogeneous Persulfate Activation by Nano-Sized $\mathrm{Mn}_{3} \mathrm{O}_{4}$ to Degrade Furfural from Wastewater. J. Mol. Liq. 2020, 298, 112088. [CrossRef]

88. Khan, A.; Zhang, K.; Sun, P.; Pan, H.; Cheng, Y.; Zhang, Y. High Performance of the A-Mn ${ }_{2} \mathrm{O}_{3}$ Nanocatalyst for Persulfate Activation: Degradation Process of Organic Contaminants via Singlet Oxygen. J. Colloid Interface Sci. 2021, 584, 885-899. [CrossRef] [PubMed]

89. Li, Y.; Liu, L.-D.; Liu, L.; Liu, Y.; Zhang, H.-W.; Han, X. Efficient Oxidation of Phenol by Persulfate Using Manganite as a Catalyst. J. Mol. Catal. A Chem. 2016, 411, 264-271. [CrossRef]

90. Xu, X.; Zhang, Y.; Zhou, S.; Huang, R.; Huang, S.; Kuang, H.; Zeng, X.; Zhao, S. Activation of Persulfate by MnOOH: Degradation of Organic Compounds by Nonradical Mechanism. Chemosphere 2021, 272, 129629. [CrossRef] [PubMed]

91. Zhang, T.; Chen, Y.; Wang, Y.; Roux, J.L.; Yang, Y.; Croué, J.-P. An Efficient Peroxydisulfate Activation Process Not Relying on Sulfate Radical Generation for Water Pollutant Degradation. Environ. Sci. Technol. 2014, 48, 5868-5875. [CrossRef] [PubMed]

92. Wang, X.; Qin, Y.; Zhu, L.; Tang, H. Nitrogen-Doped Reduced Graphene Oxide as a Bifunctional Material for Removing Bisphenols: Synergistic Effect between Adsorption and Catalysis. Environ. Sci. Technol. 2015, 49, 6855-6864. [CrossRef] [PubMed]

93. Lee, H.; Lee, H.-J.; Jeong, J.; Lee, J.; Park, N.-B.; Lee, C. Activation of Persulfates by Carbon Nanotubes: Oxidation of Organic Compounds by Nonradical Mechanism. Chem. Eng. J. 2015, 266, 28-33. [CrossRef]

94. Ahn, Y.-Y.; Yun, E.-T.; Seo, J.-W.; Lee, C.; Kim, S.H.; Kim, J.-H.; Lee, J. Activation of Peroxymonosulfate by Surface-Loaded Noble Metal Nanoparticles for Oxidative Degradation of Organic Compounds. Environ. Sci. Technol. 2016, 50, 10187-10197. [CrossRef]

95. Cheng, X.; Guo, H.; Zhang, Y.; Wu, X.; Liu, Y. Non-Photochemical Production of Singlet Oxygen via Activation of Persulfate by Carbon Nanotubes. Water Res. 2017, 113, 80-88. [CrossRef]

96. Liu, Y.; Luo, J.; Tang, L.; Feng, C.; Wang, J.; Deng, Y.; Liu, H.; Yu, J.; Feng, H.; Wang, J. Origin of the Enhanced Reusability and Electron Transfer of the Carbon-Coated $\mathrm{Mn}_{3} \mathrm{O}_{4}$ Nanocube for Persulfate Activation. ACS Catal. 2020, 10, 14857-14870. [CrossRef] 
97. Rizal, M.Y.; Saleh, R.; Taufik, A.; Yin, S. Photocatalytic Decomposition of Methylene Blue by Persulfate-Assisted $\mathrm{Ag}_{\mathrm{g}} / \mathrm{Mn}_{3} \mathrm{O}_{4}$ and $\mathrm{Ag} / \mathrm{Mn}_{3} \mathrm{O}_{4} /$ Graphene Composites and the Inhibition Effect of Inorganic Ions. Environ. Nanotechnol. Monit. Manag. 2021, 15, 100408. [CrossRef]

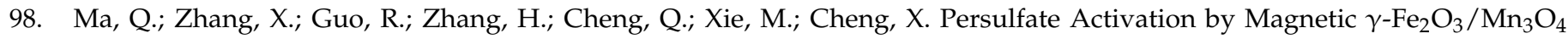
Nanocomposites for Degradation of Organic Pollutants. Sep. Purif. Technol. 2019, 210, 335-342. [CrossRef]

99. Yang, W.; Peng, Y.; Wang, Y.; Wang, Y.; Liu, H.; Su, Z.; Yang, W.; Chen, J.; Si, W.; Li, J. Controllable Redox-Induced in-Situ Growth of $\mathrm{MnO}_{2}$ over $\mathrm{Mn}_{2} \mathrm{O}_{3}$ for Toluene Oxidation: Active Heterostructure Interfaces. Appl. Catal. B Environ. 2020, 278 , 119279. [CrossRef]

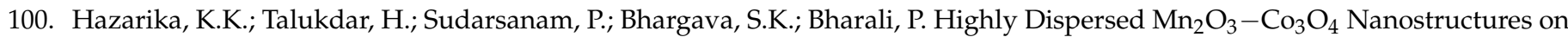
Carbon Matrix as Heterogeneous Fenton-like Catalyst. Appl. Organomet. Chem. 2020, 34, e5512. [CrossRef]

101. Wang, Y.; Chen, L.; Cao, H.; Chi, Z.; Chen, C.; Duan, X.; Xie, Y.; Qi, F.; Song, W.; Liu, J.; et al. Role of Oxygen Vacancies and Mn Sites in Hierarchical $\mathrm{Mn}_{2} \mathrm{O}_{3} / \mathrm{LaMnO}_{3}-\delta$ Perovskite Composites for Aqueous Organic Pollutants Decontamination. Appl. Catal. B Environ. 2019, 245, 546-554. [CrossRef]

102. Shokoohi, R.; Salari, M.; Shabanloo, A.; Shabanloo, N.; Marofi, S.; Faraji, H.; Tabar, M.V.; Moradnia, M. Catalytic Activation of Persulphate with $\mathrm{Mn}_{3} \mathrm{O}_{4}$ Nanoparticles for Degradation of Acid Blue 113: Process Optimisation and Degradation Pathway. Int. J. Environ. Anal. Chem. 2020, 1-20. [CrossRef]

103. Liu, D.; Li, Q.; Hou, J.; Zhao, H. Mixed-Valent Manganese Oxide for Catalytic Oxidation of Orange II by Activation of Persulfate: Heterojunction Dependence and Mechanism. Catal. Sci. Technol. 2021, 11, 3715-3723. [CrossRef]

104. Dong, Z.; Zhang, Q.; Chen, B.-Y.; Hong, J. Oxidation of Bisphenol A by Persulfate via $\mathrm{Fe}_{3} \mathrm{O}_{4}-\alpha-\mathrm{MnO}_{2}$ Nanoflower-like Catalyst: Mechanism and Efficiency. Chem. Eng. J. 2019, 357, 337-347. [CrossRef]

105. Buxton, G.V.; Greenstock, C.L.; Helman, W.P.; Ross, A.B. Critical Review of Rate Constants for Reactions of Hydrated Electrons, Hydrogen Atoms and Hydroxyl Radicals $\left(\cdot \mathrm{OH} / \cdot \mathrm{O}^{-}\right)$in Aqueous Solution. J. Phys. Chem. Ref. Data 1988, 17, 513-886. [CrossRef]

106. Wang, J.; Wang, S. Activation of Persulfate (PS) and Peroxymonosulfate (PMS) and Application for the Degradation of Emerging Contaminants. Chem. Eng. J. 2018, 334, 1502-1517. [CrossRef]

107. Kosmulski, M. Compilation of PZC and IEP of Sparingly Soluble Metal Oxides and Hydroxides from Literature. Adv. Colloid Interface Sci. 2009, 152, 14-25. [CrossRef] [PubMed]

108. Guan, Y.-H.; Ma, J.; Li, X.-C.; Fang, J.-Y.; Chen, L.-W. Influence of PH on the Formation of Sulfate and Hydroxyl Radicals in the UV/Peroxymonosulfate System. Environ. Sci. Technol. 2011, 45, 9308-9314. [CrossRef]

109. Chen, Z.; Li, X.; Zhang, S.; Jin, J.; Song, X.; Wang, X.; Tratnyek, P.G. Overlooked Role of Peroxides as Free Radical Precursors in Advanced Oxidation Processes. Environ. Sci. Technol. 2019, 53, 2054-2062. [CrossRef]

110. He, D.; Niu, H.; He, S.; Mao, L.; Cai, Y.; Liang, Y. Strengthened Fenton Degradation of Phenol Catalyzed by Core/Shell Fe-Pd@C Nanocomposites Derived from Mechanochemically Synthesized Fe-Metal Organic Frameworks. Water Res. 2019, 162, 151-160. [CrossRef]

111. Wang, L.; Jiang, J.; Pang, S.-Y.; Zhou, Y.; Li, J.; Sun, S.; Gao, Y.; Jiang, C. Oxidation of Bisphenol A by Nonradical Activation of Peroxymonosulfate in the Presence of Amorphous Manganese Dioxide. Chem. Eng. J. 2018, 352, 1004-1013. [CrossRef]

112. Sun, S.P.; Hatton, T.A.; Chung, T.-S. Hyperbranched Polyethyleneimine Induced Cross-Linking of Polyamide-imide Nanofiltration Hollow Fiber Membranes for Effective Removal of Ciprofloxacin. Environ. Sci. Technol. 2011, 45, 4003-4009. [CrossRef] [PubMed]

113. Du, X.; Zhang, Y.; Hussain, I.; Huang, S.; Huang, W. Insight into Reactive Oxygen Species in Persulfate Activation with Copper Oxide: Activated Persulfate and Trace Radicals. Chem. Eng. J. 2017, 313, 1023-1032. [CrossRef]

114. Shih, Y.; Su, Y.; Ho, R.; Su, P.; Yang, C. Distinctive Sorption Mechanisms of 4-Chlorophenol with Black Carbons as Elucidated by Different PH. Sci. Total Environ. 2012, 433, 523-529. [CrossRef]

115. Shah, N.S.; Ali Khan, J.; Sayed, M.; Ul Haq Khan, Z.; Sajid Ali, H.; Murtaza, B.; Khan, H.M.; Imran, M.; Muhammad, N. Hydroxyl and Sulfate Radical Mediated Degradation of Ciprofloxacin Using Nano Zerovalent Manganese Catalyzed $\mathrm{S}_{2} \mathrm{O}_{8}{ }^{2-}$. Chem. Eng. J. 2019, 356, 199-209. [CrossRef]

116. Huie, R.E.; Clifton, C.L.; Neta, P. Electron Transfer Reaction Rates and Equilibria of the Carbonate and Sulfate Radical Anions. Int. J. Radiat. Appl. Instrum. C Radiat. Phys. Chem. 1991, 38, 477-481. [CrossRef]

117. Chen, S.-N.; Hoffman, M.Z.; Parsons, G.H. Reactivity of the Carbonate Radical toward Aromatic Compounds in Aqueous Solution. J. Phys. Chem. 1975, 79, 1911-1912. [CrossRef]

118. Jiang, M.; Lu, J.; Ji, Y.; Kong, D. Bicarbonate-Activated Persulfate Oxidation of Acetaminophen. Water Res. 2017, 116, 324-331. [CrossRef]

119. Fang, G.-D.; Dionysiou, D.D.; Wang, Y.; Al-Abed, S.R.; Zhou, D.-M. Sulfate Radical-Based Degradation of Polychlorinated Biphenyls: Effects of Chloride Ion and Reaction Kinetics. J. Hazard. Mater. 2012, 227-228, 394-401. [CrossRef]

120. Qi, C.; Liu, X.; Li, Y.; Lin, C.; Ma, J.; Li, X.; Zhang, H. Enhanced Degradation of Organic Contaminants in Water by Peroxydisulfate Coupled with Bisulfite. J. Hazard. Mater. 2017, 328, 98-107. [CrossRef]

121. Lei, Y.; Chen, C.-S.; Tu, Y.-J.; Huang, Y.-H.; Zhang, H. Heterogeneous Degradation of Organic Pollutants by Persulfate Activated by $\mathrm{CuO}-\mathrm{Fe}_{3} \mathrm{O}_{4}$ : Mechanism, Stability, and Effects of PH and Bicarbonate Ions. Environ. Sci. Technol. 2015, 49, 6838-6845. [CrossRef] [PubMed] 
122. Liang, C.; Wang, Z.-S.; Mohanty, N. Influences of Carbonate and Chloride Ions on Persulfate Oxidation of Trichloroethylene at $20^{\circ}$ C. Sci. Total Environ. 2006, 370, 271-277. [CrossRef]

123. Zhou, J.; Xiao, J.; Xiao, D.; Guo, Y.; Fang, C.; Lou, X.; Wang, Z.; Liu, J. Transformations of Chloro and Nitro Groups during the Peroxymonosulfate-Based Oxidation of 4-Chloro-2-Nitrophenol. Chemosphere 2015, 134, 446-451. [CrossRef] [PubMed]

124. Yang, Y.; Pignatello, J.J.; Ma, J.; Mitch, W.A. Comparison of Halide Impacts on the Efficiency of Contaminant Degradation by Sulfate and Hydroxyl Radical-Based Advanced Oxidation Processes (AOPs). Environ. Sci. Technol. 2014, 48, 2344-2351. [CrossRef] [PubMed]

125. Grebel, J.E.; Pignatello, J.J.; Mitch, W.A. Effect of Halide Ions and Carbonates on Organic Contaminant Degradation by Hydroxyl Radical-Based Advanced Oxidation Processes in Saline Waters. Environ. Sci. Technol. 2010, 44, 6822-6828. [CrossRef] [PubMed]

126. Yang, Y.; Pignatello, J.J.; Ma, J.; Mitch, W.A. Effect of Matrix Components on UV $/ \mathrm{H}_{2} \mathrm{O}_{2}$ and UV/S $\mathrm{O}_{8}{ }^{2-}$ Advanced Oxidation Processes for Trace Organic Degradation in Reverse Osmosis Brines from Municipal Wastewater Reuse Facilities. Water Res. 2016, 89, 192-200. [CrossRef]

127. Minakata, D.; Kamath, D.; Maetzold, S. Mechanistic Insight into the Reactivity of Chlorine-Derived Radicals in the AqueousPhase UV-Chlorine Advanced Oxidation Process: Quantum Mechanical Calculations. Environ. Sci. Technol. 2017, 51, 6918-6926. [CrossRef]

128. Wang, J.; Wang, S. Effect of Inorganic Anions on the Performance of Advanced Oxidation Processes for Degradation of Organic Contaminants. Chem. Eng. J. 2021, 411, 128392. [CrossRef] 